\title{
Heterogeneous Hydrogenation of Quinoline Derivatives Effected by a Granular Cobalt Catalyst
}

\author{
Daniel Timelthaler \\ Christoph Topf* \\ Institute of Catalysis (INCA), Johannes Kepler University (IKU), \\ Altenbergerstraße 69, 4040 Linz, Austria \\ christoph.topf@jku.at
}

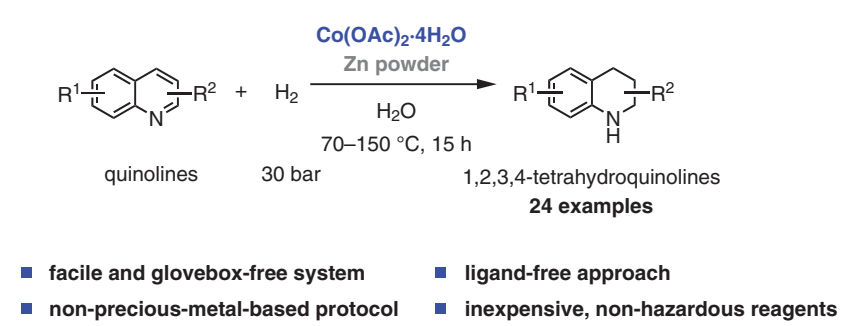

Received: 09.07.202

Accepted after revision: 14.09.2021

Published online: 14.09 .2021

DOI: 10.1055/a-1654-3302; Art ID: ss-2021-z0404-fa

License terms: (c)

(c) 2022. The Author(s). This is an open access article published by Thieme under the terms of the Creative Commons Attribution License, permitting unrestricted use, distribution and reproduction, so long as the original work is properly cited. (https://creativecommons.org/licenses/by/4.0/)

Abstract We communicate a convenient method for the pressure hydrogenation of quinolines in aqueous solution by using a particulate cobalt-based catalyst that is prepared in situ from simple $\mathrm{Co}(\mathrm{OAc})_{2} \cdot 4 \mathrm{H}_{2} \mathrm{O}$ through reduction with abundant zinc powder. This catalytic protocol permits a brisk and atom-efficient access to a variety of 1,2,3,4-tetrahydroquinolines thereby relying solely on easy-to-handle reagents that are all readily obtained from commercial sources. Both the reaction setup assembly and the autoclave charging procedure are conducted on the bench outside an inert-gas-operated containment system, thus rendering the overall synthesis time-saving and operationally very simple.

Key words heterogeneous catalysis, hydrogenation, cobalt, zinc, tetrahydroquinolines

1,2,3,4-Tetrahydroquinoline derivatives (THQs) are $\mathrm{N}$-heterocyclic key motifs that are found in a vast array of interesting pharmacologically active compounds and, consequently, their cost-effective and rational syntheses are highly rewarding and sought-after. ${ }^{1}$ In this context, the catalytic hydrogenation of the corresponding quinoline derivatives, by either homogeneous or heterogeneous strategies, represents a worthwhile approach for the preparation of the targeted THQ compounds by virtue of the unmitigated atom efficiency of $\mathrm{H}_{2}$-driven reductions. ${ }^{2}$

Whereas noble-metal-based homogeneous hydrogenation protocols utilize $\mathrm{Rh},{ }^{3} \mathrm{Ir},{ }^{4} \mathrm{Ru},{ }^{5} \mathrm{Pd},{ }^{6}$ or Os, ${ }^{7}$ base-metalrelated approaches mainly deploy $\mathrm{Mn}^{8,9} \mathrm{Fe}^{8,10} \mathrm{Mo},{ }^{11}$ or $\mathrm{Co}^{8,12}$ (vide infra) as catalytically active metal centers. Regarding cobalt, certain complexes thereof were also demon- strated to function as transfer hydrogenation catalysts that enable the quinoline reduction by using either formic acid ${ }^{13}$ or the ammonia-borane adduct ${ }^{14}$ as hydrogen source. In a similar vein, simple $\mathrm{Cu}\left(\mathrm{ClO}_{4}\right)_{2}$ facilitates the reduction of the given $\mathrm{N}$-heterocycles by employing the oxazaborolidine complex. ${ }^{15}$ By contrast, transfer hydrogenation strategies nation compounds as catalysts.

The heterogeneous hydrogenation of quinolines is carried out using again either precious or non-noble metals. ${ }^{19}$ With respect to the former, related protocols rely on the deployment of $\mathrm{Pd},{ }^{20} \mathrm{Rh}^{20 \mathrm{e}, 21} \mathrm{Ru}^{20 \mathrm{e}, 22} \mathrm{Ir}^{20 \mathrm{e}, 23} \mathrm{Pt}^{20 \mathrm{e}, 24}$ or $\mathrm{Au},{ }^{25}$ tered around the implementation of $\mathrm{Cu}^{26} \mathrm{Fe}^{27} \mathrm{Ni}^{28}$ or $\mathrm{Co}^{29}$ in MOF-derived or supported (composite) materials. The latter type of solid catalysts is frequently prepared through pyrolysis of well-defined metal complexes ${ }^{30}$ that are grafted onto suitable carriers by wet-impregnation prior to thermal heat treatment under an inert gas atmosphere. In this respect, cobalt ${ }^{31}$ plays a dominant role in the manufacture of such nanocomposites by virtue of its good abundance and decent redox activity. Consequently, pyrolytically activated cobalt complexes have also been successfully applied in the related transfer hydrogenation of quinolines. ${ }^{32}$

On the other hand, free cobalt nanoparticles ${ }^{33}$ have also been shown to bring about the title transformation. Howevhydrous $\mathrm{CoX}_{2}(\mathrm{X}=\mathrm{Cl}$ or $\mathrm{Br})$ in combination with moistureand/or air-sensitive reductants such as $\mathrm{LiBHEt}_{3},{ }^{34} \mathrm{NaBH}_{4},{ }^{35}$ or lithium naphthalenide. ${ }^{36}$

Interestingly, the popular RANEY ${ }^{\circledR}$ cobalt has not yet been reported to catalyze the reduction of quinolines with $\mathrm{H}_{2}$ gas, ${ }^{37}$ whereas the congeneric and significantly more reactive RANEY ${ }^{\circledR}$ nickel does bring about the given reduction, either with gaseous $\mathrm{H}_{2}{ }^{38}$ or with water as the sole hydrogen source. ${ }^{39}$ It is worth mentioning here that the kindred that rely on precious metals utilize $\mathrm{Ru},{ }^{16} \mathrm{Rh},{ }^{17}$ or $\mathrm{Ir}^{18}$ coordiwhereas non-noble-metal-based strategies are well cener, most of the corresponding protocols entail the use of an- 
Urushibara-type nickel is a useful catalyst for the deoxygenation of both quinoline $\mathrm{N}$-oxides and pyridine $\mathrm{N}$-oxides to yield the corresponding untagged $\mathrm{N}$-heterocycles. ${ }^{40}$

Strikingly, it was also demonstrated that the non-noble main group metal Ba also efficiently catalyzes the heterogeneous hydrogenation of quinoline to 1,2,3,4-tetrahydroquinoline. ${ }^{41}$

Within a slightly different context, a granular catalyst prepared from $\mathrm{CoBr}_{2}$ and pyrophoric $\mathrm{NaBHEt}_{3}$ was demonstrated to facilitate the heterogeneous hydrogenation of nitriles to afford primary amines. ${ }^{42}$ Quite recently, we reported on a solid cobalt catalyst which was generated in situ through reduction of simple hydrated $\mathrm{Co}(\mathrm{OAc})_{2}$ with harmless zinc powder and that brought about the same catalytic transformation. ${ }^{43}$ In order to expand upon the scope of our $\mathrm{Co}(\mathrm{II}) / \mathrm{Zn}(0)$ approach, we initially tested parent quinoline 1a as substrate for the pertinent heterogeneous hydrogenation reaction.

On applying $\mathrm{Co}(\mathrm{OAc})_{2} \cdot 4 \mathrm{H}_{2} \mathrm{O}(5 \mathrm{~mol} \%)$ and fine $\mathrm{Zn}$ dust (50 mol\%), we were delighted to promptly observe full conversion of the starting material, resulting in an excellent yield of the desired tetrahydroquinoline $2 \mathbf{a}$ at $70{ }^{\circ} \mathrm{C}$ and under $\mathrm{H}_{2}$ (40 bar) after overnight reaction (Table 1, entry 1 ). Moreover, GC-MS analyses of the quenched reaction mixture did not indicate the formation of any byproduct.

Encouraged by these initial positive results, we attempted to find milder reaction conditions, while at the same time maintaining decent catalytic activity of the heterogeneous in situ system. As a first step, we aimed to reduce the
Table 1 Optimization of the Reaction Conditions for the Cobalt-Catalyzed Hydrogenation of Quinoline ${ }^{\mathrm{a}}$

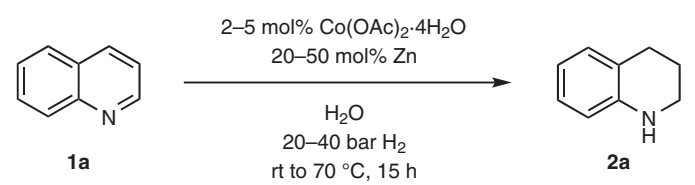

\begin{tabular}{|c|c|c|c|c|c|c|}
\hline Entry & $\begin{array}{l}\mathrm{Co}(\mathrm{OAc})_{2} \cdot 4 \mathrm{H}_{2} \mathrm{O} \\
(\mathrm{mol} \%)\end{array}$ & $\begin{array}{l}\mathrm{Zn} \\
\text { (mol\%) }\end{array}$ & $\begin{array}{l}\text { Temp } \\
\left({ }^{\circ} \mathrm{C}\right)\end{array}$ & $\begin{array}{l}\mathrm{H}_{2} \text { pressure } \\
\text { (bar) }\end{array}$ & Conv. ${ }^{\mathrm{b}}(\%)$ & $\begin{array}{l}\text { Yield }{ }^{\mathrm{b}} \\
(\%)\end{array}$ \\
\hline 1 & 5 & 50 & 70 & 40 & $>99$ & 99 \\
\hline 2 & 5 & 50 & 70 & 30 & $>99$ & 99 \\
\hline 3 & 5 & 50 & 60 & 30 & $>99$ & 97 \\
\hline 4 & 5 & 50 & 40 & 30 & 19 & 19 \\
\hline 5 & 5 & 50 & $\mathrm{rt}$ & 30 & 17 & 13 \\
\hline 6 & 2.5 & 25 & 70 & 30 & $>99$ & 99 \\
\hline 7 & 2 & 20 & 70 & 30 & 65 & 64 \\
\hline 8 & 5 & 50 & 70 & 20 & $>99$ & 97 \\
\hline 9 & 2.5 & 25 & 70 & 20 & 98 & 95 \\
\hline
\end{tabular}

a Reaction conditions: 1 a $(0.5 \mathrm{mmol}), \mathrm{H}_{2} \mathrm{O}(1.5 \mathrm{~mL})$.

b Determined by GC-MS analysis using chlorobenzene as internal standard.

$\mathrm{H}_{2}$ pressure from 40 bar to 30 bar, which was indeed achieved without any loss of either conversion or yield (Table 1, entry 2). Next, the reaction temperature was gradually decreased from $70{ }^{\circ} \mathrm{C}$ to room temperature (entries 2-5) and, rewardingly, the reaction still produced an excellent

\section{Biographical Sketches}

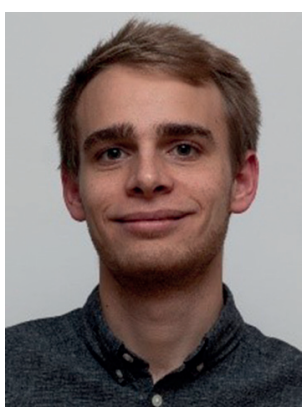

Daniel Timelthaler received his B.Sc. in Technical Chemistry at the Johannes Kepler University (JKU) in Linz, Austria in 2016 on synthetic organic chemistry in the group of M. Waser. He then earned his Diploma at JKU in 2019 in the group of C. Topf for the development of nickeland cobalt-based catalyst systems. After a following 4 months language course in
China, he began his PhD in the research group of $C$. Topf on non-precious-metal-based hydrogenation catalysts.

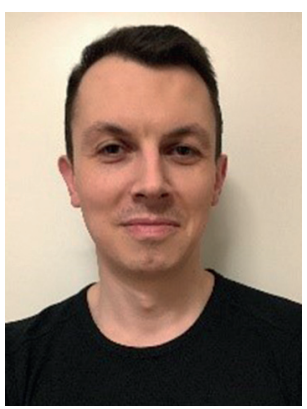

Christoph Topf studied Technical Chemistry at the Johannes Kepler University (JKU) in Linz, Austria, and received his Diploma (2009) for work with U. Monkowius on coinage metalNHC complexes. Later, he earned his PhD (2012) under the guidance of $\mathrm{G}$. Knör for the synthesis and characterization of a biomimetic [FeFe] hydrogenase model compound. Hereafter, he moved to the Leibniz Institute of Catalysis (LIKAT) in Rostock, Germany, where he joined the group of M. Beller to carry out postdoctoral research into base-metal-catalyzed homogeneous and heterogeneous hydrogenation reactions. In
2016, he returned to Linz where he co-founded the Institute of Catalysis (INCA) at the JKU. Currently, Christoph finishes his habilitation under the mentorship of M. Hapke in the field of nonprecious-metal-based redox catalysis. 
yield of compound $\mathbf{2 a}$ at a temperature of $60{ }^{\circ} \mathrm{C}$. Further reduction to $40{ }^{\circ} \mathrm{C}$ or even to room temperature caused a steep decline of activity, thus rendering these conditions non-suitable for the target transformation.

Deterred by the high metal loadings of $5 \mathrm{~mol} \% \mathrm{Co}$ and 50 mol\% $\mathrm{Zn}$, respectively, we consequently performed the model reaction with lower amounts of the $\mathrm{Co}(\mathrm{II})$ precursor salt and the zinc additive whilst keeping the Co/Zn ratio constant. Strikingly, full conversion of the benchmark quinoline 1a and almost quantitative yield of $\mathbf{2 a}$ was also achieved at $70{ }^{\circ} \mathrm{C}$ and 30 bar $\mathrm{H}_{2}$ with a halved amount of the given components, i.e. Co salt ( $2.5 \mathrm{~mol} \%)$ and $\mathrm{Zn}(25 \mathrm{~mol} \%)$ (entry 6). However, further attempts at reducing the catalyst loading and the $\mathrm{H}_{2}$ pressure resulted in a significant loss in catalytic activity of our in situ system (entries 7-9).

It is worth mentioning here that, in stark contrast to our previous work on nitrile hydrogenation with a similar catalytic system, ${ }^{43}$ a tenfold molar excess of the reductant versus $\mathrm{Co}(\mathrm{II})$ is necessary to effect full substrate conversion. Corresponding experiments directed at reducing the $\mathrm{Co} / \mathrm{Zn}$ molar ratio to $1: 5$ or $1: 3$ with respect to a $\mathrm{Co}$ (II) salt loading of $2.5 \mathrm{~mol} \%$ resulted in a sharp drop in conversion to $58 \%$ and $13 \%$, respectively (see Supporting Information, SI, Table $\mathrm{S} 2$, entries 5 and 6 ). The influence of the ratio of the $\mathrm{Co}(\mathrm{II})$ precursor salt and the $\mathrm{Zn}$ metal on the catalyst performance is further outlined in a conversion-time diagram (Figure 1). It clearly shows that the conversion of $\mathbf{1 a}$ is brought to completion after a period of 15 hours if the initial $\mathrm{Zn}$ loading is doubled (gray trace vs red trace). Interestingly, applying twice the amount of the cobalt salt, whilst keeping the original Zn quantity fixed, does not further expedite the given catalytic transformation (green curve). On the other hand, doubling the $\mathrm{Co}(\mathrm{II})$ and the $\mathrm{Zn}(0)$ portion simultaneously gives rise to full conversion after a reaction time of only 6 hours (blue trace).

To illustrate the heterogeneous nature of the catalyst described here, we first performed a Hg-poisoning experiment. For this purpose, the pertinent catalytic transformation was conducted in the presence of a few drops of elemental mercury. We did not detect any tetrahydroquinoline $\mathbf{2 a}$, and it is noteworthy that the reaction solution adopted a pink turbid appearance, which indicated the formation of a $\mathrm{Zn}-\mathrm{Hg}$ amalgam that effectively prohibited the vital reduction of $\mathrm{Co}$ (II) to active $\mathrm{Co}(0)$ particles. Furthermore, we conducted Maitlis's hot filtration test ${ }^{44}$ under inert conditions so as to establish the particulate character of the activated catalyst. Accordingly, the hydrogenation of quinoline 1a was allowed to proceed for 6 hours, whereupon the reaction solution was filtered through a PTFE membrane ( $0.2 \mu \mathrm{m}$ pore size). The catalytic transformation was then re-enacted with the obtained clear filtrate and, as expected, the catalytic activity had completely ceased after
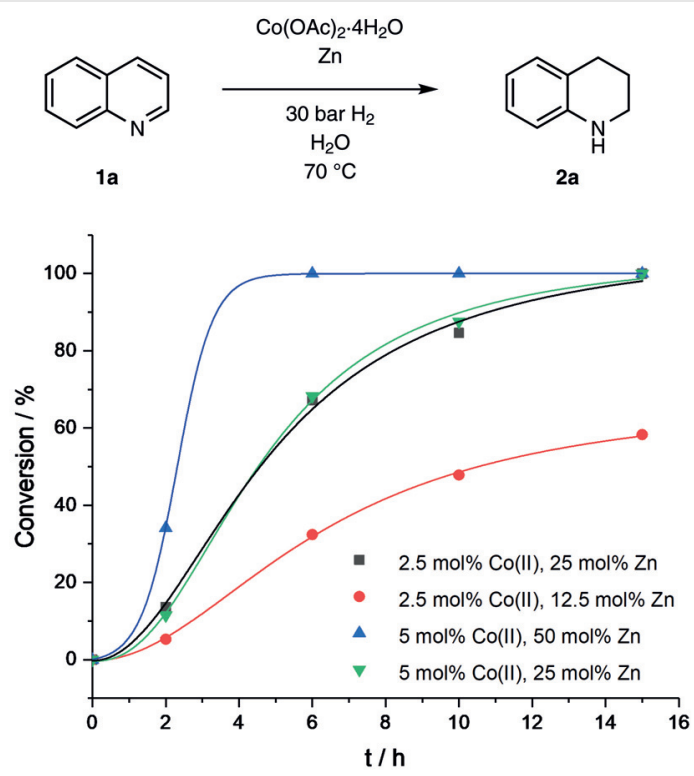

Figure 1 Conversion vs time diagram of the Co-catalyzed heterogeneous hydrogenation of quinoline (1a) to tetrahydroquinoline (2a), showing the influence of catalyst loading and the $\mathrm{Co}(\mathrm{II}) / \mathrm{Zn}(0)$ molar ratio (substrate conversion determined by GC analysis using chlorobenzene as internal standard)

this procedure. Since the active material was fully retained by the filter that was used, the catalyst particles fall outside the nanoscopic scale $(1-100 \mathrm{~nm}){ }^{45}$

Next, we decided to study the influence of the reaction medium on the performance of our in situ prepared heterogeneous cobalt catalyst. In this context, a recent report from the groups of Fischmeister and Beller ${ }^{35}$ communicates the suitability of water as a green and benign solvent for the heterogeneous hydrogenation of quinoline derivatives. Inspired by this finding, we decided to use the same solvent in our initial catalytic experiments described herein. To assess the influence of the reaction medium, we performed the hydrogenation of model compound $\mathbf{1 a}$ in various solvents at $70{ }^{\circ} \mathrm{C}$ under $\mathrm{H}_{2}$ (30 bar) by using $\mathrm{Co}(\mathrm{OAc})_{2} \cdot 4 \mathrm{H}_{2} \mathrm{O}(2$ $\mathrm{mol} \%$ ) and $\mathrm{Zn}$ (20 mol\%) (SI, Table S1). Strikingly, under these reaction conditions, the presence of water proved to be indispensable for the Co particles to develop catalytic activity. Neither polar protic solvents such as short-chain alcohols and acetonitrile nor nonpolar toluene enabled the formation of any product $\mathbf{2 a}$. Regrettably, the same negative result was found for the otherwise excellent solvent THF. For the sake of completeness, we also conducted the catalytic reaction in neat quinoline, but also in this case the amount of 1,2,3,4-tetrahydroquinoline was negligibly small in the reaction mixture (Table S1, entries 1-8). 
Having identified water as the best solvent for this Cobased in situ system, we then investigated the influence of various additives on the catalytic activity. With the intention to activate quinoline 1a through electrophilic interaction, the hydrogenation experiment was run in the presence of the Lewis acids $\mathrm{Zn}(\mathrm{OTf})_{2}$ or $\mathrm{Al}(\mathrm{OTf})_{3}$. Surprisingly, both triflates had a deleterious impact on product formation in that we were not able to detect any desired $\mathbf{2 a}$ via GC-MS analysis (SI, Table S1, entries 9 and 10). Addition of a Brønsted acid or base turned out to be unsuitable for the reaction too. It is worth mentioning here that in our previous work on nitrile hydrogenation enabled by a similar catalyst system, ${ }^{43}$ both ammonia and triflate-based Lewis acids were useful additives that increased the catalyst's activity and curbed the formation of detrimental side products. Regrettably, these positive effects were not reproduced within the cobalt-catalyzed quinoline hydrogenation described herein (entries 11-14).

Additionally, we anticipated that the use of surfactants as emulsifying agents ${ }^{46}$ would expedite the catalytic transformation, since these compounds are supposed to increase the materials exchange between the gas phase and the liquid portion of the reaction mixture. In fact, however, our approaches employing sodium dodecyl sulfate (SDS), polyethylene glycol (PEG), and a commercial detergent failed to improve the catalyst activity (SI, Table S1, entries 15-17).

In light of the forgoing experimental results, we decided to elaborate the catalytic protocol without any further additives, thus rendering the synthetic procedure simple and time-saving.

Subsequently, we probed several $\mathrm{Co}$ (II) salts for their aptitude to function as precursors for the in situ generation of the granular metal catalyst. Simple $\mathrm{Co}(\mathrm{OAc})_{2} \cdot 4 \mathrm{H}_{2} \mathrm{O}$ used from the very start provided the best results in terms of substrate conversion and product yield. In contrast, the congeneric $\mathrm{CoCl}_{2} \cdot 6 \mathrm{H}_{2} \mathrm{O}$ and $\mathrm{Co}\left(\mathrm{BF}_{4}\right)_{2} \cdot 6 \mathrm{H}_{2} \mathrm{O}$ were both heavily outperformed by the acetate (SI, Table S2, entries 9 and 10). Anhydrous $\mathrm{CoI}_{2}$ furnished particles of only minute activity, whereas the solid material derived from $\mathrm{CoF}_{3}$ and $\left[\mathrm{Co}(\mathrm{acac})_{2}\right]$ did not enable the formation of any tetrahydroquinoline 2a at all (entries 11-13). Lastly, we carried out blank tests without any $\mathrm{Co}(\mathrm{II})$ sources and, as expected, product formation was not observed by GC-MS (entries 19 and 21).

We continued testing different reducing agents for their ability to produce the active $\operatorname{Co}(0)$ particles from the respective acetate precursor. While previously reported systems rely on highly reactive but very air- and moisture sensitive reductants such as $\mathrm{NaBH}_{4},{ }^{35} \mathrm{NaBHEt}_{3},{ }^{42} \mathrm{LiBHEt}_{3},{ }^{34}$ $\mathrm{LiAlH}_{4},{ }^{47}$ or lithium naphthalenide ${ }^{36}$ for the (in situ) preparation of the Co-based catalyst material, we aimed to employ air-stable and easy-to-handle electropositive metals other than zinc. As summarized in the SI, Table S2, the hydrogenation experiments carried out with powdered manganese, magnesium, or iron did not yield any tetrahydro- quinoline 2a, although minor conversion of starting material 1a was observed in all three cases (entries 14-16). It is noteworthy that when the popular reductant sodium dithionite was used, the catalytic activity fully collapsed, because $\mathrm{Co}(\mathrm{II})$ was not transformed into $\mathrm{Co}(0)$, since the color of the reaction solution remained pink (entry 18). Yet the addition of aluminum enabled the formation of some tetrahydroquinoline product, namely $8 \%$ yield, although this value still seriously lagged behind that of the $\mathrm{Zn}$ approach (entries 17 and 7).

After the systematic variation of the physical reaction parameters and the additives, we explored the scope and limitations of this heterogeneous Co-based hydrogenation protocol. As summarized in Scheme 1, selected structurally diverse quinolines $\mathbf{1}$ were neatly converted into the corresponding tetrahydroquinoline products $\mathbf{2}$ after reaction overnight at $70-150{ }^{\circ} \mathrm{C}$ and under $\mathrm{H}_{2}$ (30 bar), whereby the reaction temperature and the catalyst loading were markedly substrate-dependent. It is worth mentioning here that the isolation of the products was considerably alleviated by the addition of anhydrous $\mathrm{Na}_{2} \mathrm{SO}_{4}$ to the quenched reaction mixture and subsequent filtration of the thus-obtained suspension over cotton wool, since this procedure removes the water and the catalyst particles in a single step.

The benchmark quinoline 1a gave rise to an almost quantitative yield of $\mathbf{2 a}$ (96\%), and this value was perfectly reproduced when a tenfold or twentyfold amount of starting material was used (Scheme 1). The methyl groups on the pyridine moiety of quinolines $\mathbf{1 b}$-d necessitated a doubling of the catalyst loading to achieve appreciable product formation. Moreover, the position of the methyl group had a strong impact on the required reaction temperature; the further away the methyl group was from the $\mathrm{sp}^{2}$ nitrogen of the heterocycle, the more thermal energy had to be applied to maintain a decent product yield. It is important to note that compounds $\mathbf{2 b}$ and $\mathbf{2 d}$ are used as precursors for the manufacture of an antitrypanosomal compound ${ }^{48}$ and a CNS depressant agent, ${ }^{49}$ respectively (Scheme 2 ). However, it has to be stressed here that the hydrogenation of substrate 1d afforded a substantial portion of the converse and non-desired 5,6,7,8-tetrahydroquinoline (Scheme 1).

When the methyl substituents were located on the benzene core, the corresponding tetrahydroquinolines $\mathbf{2 e -} \mathbf{g}$ were all obtained in excellent yields, all exceeding 95\% (Scheme 1). However, twice the amount of catalyst had to be applied when the methyl motif was located at position 7 or 8 of the corresponding quinoline. Quite remarkably, the heterogeneous hydrogenation of ionic $N$-methylquinolinium iodide 1w, which has the methyl group at position 1 , produced significantly lower amounts of the product $(23 \%$ yield) compared to its neutral congeners 1a-g (56-97\% yield).

Continuing with methoxy-functionalized substrates $\mathbf{1 h}-\mathbf{j}$ (Scheme 1), we found that these derivatives gave rise to excellent yields ( $\geq 95 \%$ throughout) of the corresponding 

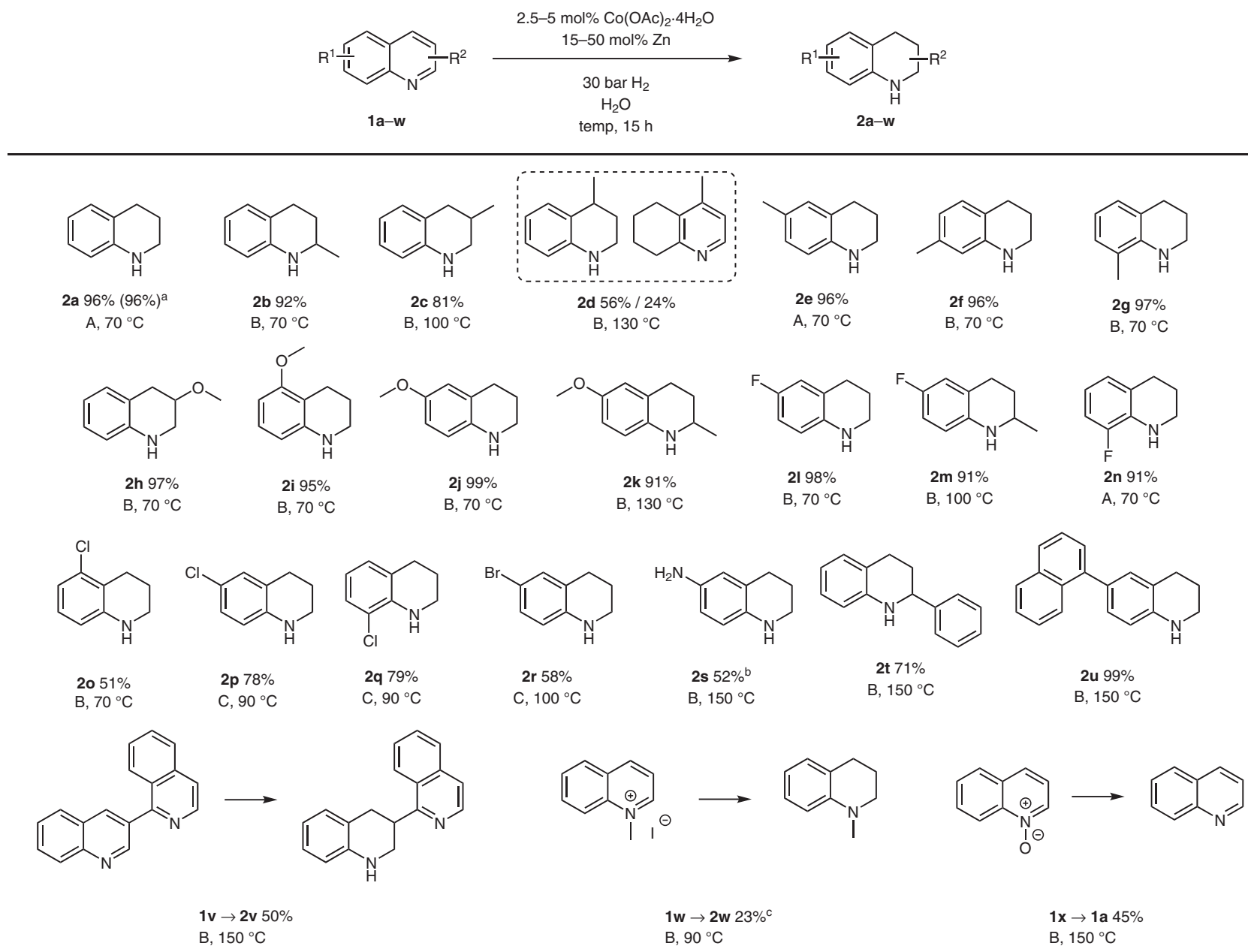

Scheme 1 Cobalt-catalyzed heterogeneous hydrogenation of quinoline derivatives $\mathbf{1 a - w}$ using catalyst loadings A-C. Reagents and conditions: quinoline $1(0.5 \mathrm{mmol}), \mathrm{H}_{2} \mathrm{O}(1.5 \mathrm{~mL})$, temperature as indicated, $\mathrm{H}_{2}$ (30 bar), $15 \mathrm{~h}$, catalyst assembly $\mathrm{A}: \mathrm{Co}(\mathrm{OAc})_{2} \cdot 4 \mathrm{H}_{2} \mathrm{O}(2.5 \mathrm{~mol} \%), \mathrm{Zn}(25 \mathrm{~mol} \%) ; \mathrm{B}$ : $\mathrm{Co}(\mathrm{OAC})_{2} \cdot 4 \mathrm{H}_{2} \mathrm{O}(5 \mathrm{~mol} \%), \mathrm{Zn}(50 \mathrm{~mol} \%) ; \mathrm{C}: \mathrm{Co}(\mathrm{OAc})_{2} \cdot 4 \mathrm{H}_{2} \mathrm{O}(5 \mathrm{~mol} \%), \mathrm{Zn}(15 \mathrm{~mol} \%)$; isolated yields shown. ${ }^{\text {a }}$ This value was obtained using either $5 \mathrm{mmol}$ or $10 \mathrm{mmol}$ of the substrate. ${ }^{\mathrm{b}}$ Additive of $3 \mathrm{M}$ aq HCl $(10 \mu \mathrm{L})$ used (product yield determined by ${ }^{1} \mathrm{H}$ NMR using cyclohexane as internal standard). ${ }^{\mathrm{C}} \mathrm{H}_{2} \mathrm{O} / \mathrm{MeOH}$ (1:1 by volume) mixture used as solvent.

1,2,3,4-tetrahydroquinolines at $70{ }^{\circ} \mathrm{C}$, which is of significant practical relevance given that compound $\mathbf{2 j}$ is a sought-after precursor to a tubulin polymerization inhibitor (Scheme 2).$^{50}$ Notably, putting a methyl group in immediate spatial proximity to the $\mathrm{N}$ atom of the heterocycle diminished the reactivity of $\mathbf{1 k}$ to such an extent that the temperature had to be increased to $130{ }^{\circ} \mathrm{C}$ so as to allow sound product formation (Scheme 1).

With respect to halogenated quinolines, the fluoro derivatives 11-n were cleanly transformed to the desired semi-hydrogenated $\mathrm{N}$-heterocycles (91-98\% yield), but we again observed the deleterious effect of a methyl motif adjacent to the $\mathrm{sp}^{2} \mathrm{~N}$ atom as in the case of $1 \mathbf{m}\left(100{ }^{\circ} \mathrm{C}\right.$ for $\mathbf{1 m}$ vs $70{ }^{\circ} \mathrm{C}$ for $\mathbf{1 1}$ and $\mathbf{1 n}$ ) (Scheme 1). Importantly, the corresponding tetrahydroquinoline product $\mathbf{2 m}$ is the starting material for the synthesis of the antibiotic drug flumequine (Scheme 2). ${ }^{51}$ Contrasting with these pleasing results ob- tained for the fluoro compounds are the reaction outcomes observed for the kindred chloro- and bromo-substituted quinolines 1o-r (Scheme 1). These derivatives proved to be significantly prone to hydrodehalogenation, which significantly lowered the yields of the products $2 \mathbf{o}-\mathbf{r}(51-79 \%)$. For the haloquinolines 1p, 1q, and 1r, the extent of this detrimental side reaction was only mitigated through the reduction of the $\mathrm{Zn}$ loading from $50 \mathrm{~mol} \%$ to $15 \mathrm{~mol} \%$ versus the substrate in combination with an increase of the reaction temperature to compensate for the diminished catalyst activity (vide supra). At this point it must be emphasized that the given heterogeneous Co-catalyzed hydrogenation of substrates bearing a $\mathrm{Cl}$ substituent on any position of the pyridine moiety of the substrate molecule solely afforded pure, non-substituted tetrahydroquinoline $\mathbf{2 a}$ as a result of full dehydrohalogenation. 
<smiles>Cc1ccc2ccccc2n1</smiles>

$1 b$<smiles>Cc1ccnc2ccccc12</smiles>

1d<smiles>COc1ccc2ncccc2c1</smiles>

1j

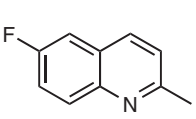

$1 \mathrm{~m}$

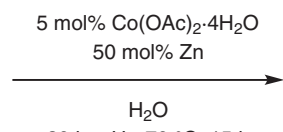

30 bar $\mathrm{H}_{2}, 70{ }^{\circ} \mathrm{C}, 15 \mathrm{~h}$

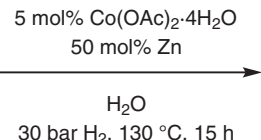

30 bar $\mathrm{H}_{2}, 130{ }^{\circ} \mathrm{C}, 15 \mathrm{~h}$

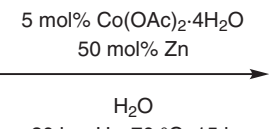

30 bar $\mathrm{H}_{2}, 70^{\circ} \mathrm{C}, 15 \mathrm{~h}$

$5 \mathrm{~mol} \% \mathrm{Co}(\mathrm{OAc})_{2} \cdot 4 \mathrm{H}_{2} \mathrm{O}$

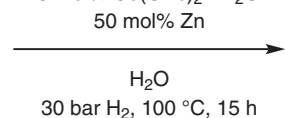

30 bar $\mathrm{H}_{2}, 100^{\circ} \mathrm{C}, 15 \mathrm{~h}$<smiles>CC1CCc2ccccc2N1</smiles>

2b, $92 \%$

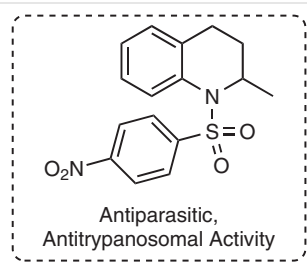<smiles>CC1CCNc2ccccc21</smiles>

2d, $56 \%$

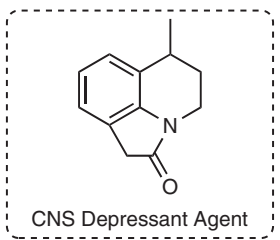<smiles>CC1CCc2cc(F)ccc2N1</smiles>

2m, $91 \%$<smiles>COc1ccc2c(c1)CCCN2</smiles>

2j, $99 \%$<smiles>CC1CCc2cc(F)cc3c(=O)c(C(=O)O)cn1c23</smiles>

Scheme 2 Overview of the syntheses of pharmaceutically relevant precursors that are accessible through this cobalt-catalyzed reaction

Aminoquinoline 2s, with its exposed lone pair on the amine $\mathrm{sp}^{3} \mathrm{~N}$ atom, turned out to be a rather recalcitrant substrate for the given Co-based hydrogenation protocol (Scheme 1). This is presumably due to the fact that $\mathbf{2 s}$ effectively poisons the catalyst through coordination of the $\mathrm{NH}_{2}$ group onto the surface of the active particles. This unwanted catalyst deactivation process was, at least to some extent, curbed by the addition of aqueous $\mathrm{HCl}$ solution to the reaction mixture.

The presence of aryl groups, as in $\mathbf{1 t}$ and $\mathbf{1 u}$, was well accommodated by our in situ system, although elevated reaction temperatures had to be applied for full conversion and satisfactory yields of tetrahydroquinolines $\mathbf{2 t}$ and $\mathbf{2 u}$, whereby the pendent aromatics remained unaffected by the catalytic transformation (Scheme 1). Within a similar context, the hydrogenation of the mixed substrate $\mathbf{1 v}$ demonstrated that the described catalyst system sharply discriminates between quinoline and the structurally very similar isoquinoline motif, whereby the latter remained untouched after hydrogenation.
We were further interested in testing the ability of the Co catalyst to reduce quinolinium $\mathrm{N}$-oxide $\mathbf{1} \mathbf{x}$ to the parent quinoline 1a (Scheme 1), as the former is a common functional group that is encountered in a variety of ring-functionalization processes. Strikingly, the given catalyst selectively oxygenated $\mathbf{1 x}$ to exclusively form quinoline $\mathbf{1 a}$, with no consecutive reaction leading to 1,2,3,4-tetrahydroquinoline 2a observed as long as $\mathrm{N}$-oxide was present in the reaction mixture. To our regret, this catalytic reaction was sluggish and forced reaction conditions $\left(150^{\circ} \mathrm{C}\right)$ were required for obtaining acceptable yields.

Apart from quinolines, the catalytic system also facilitated the heterogeneous hydrogenation of other $\mathrm{N}-, \mathrm{O}-$, and S-heterocycles (Table 2). Especially noteworthy is the hydrogenation of biomass-derived furfural 1ab, since the reaction outcome was controlled by variation of the temperature, such that either alcohol 2ab or the exhaustive hydrogenation product 2ab' was obtained. As expected, the catalytic transformation of thiophene 1ac to afford tetrahydrothiophene (THT) 2ac was not successful, owing to the 
intrinsic catalyst-poisoning-nature of the $\mathrm{S}$ atom; even with a catalyst loading as high as $8 \mathrm{~mol} \% \mathrm{Co}(\mathrm{II})$ no hydrogenation of the S-heterocycle was observed.

Table 2 Cobalt-Catalyzed Heterogeneous Hydrogenation of Selected $\mathrm{N}-, \mathrm{O}-$, and S-Heteroarenes other than Quinolines ${ }^{\mathrm{a}}$

Substrate Temp $\left({ }^{\circ} \mathrm{C}\right)$

${ }^{a}$ Reaction conditions: 1 ( $\left.0.5 \mathrm{mmol}\right), \mathrm{Co}(\mathrm{OAc})_{2} \cdot 4 \mathrm{H}_{2} \mathrm{O}(5 \mathrm{~mol} \%), \mathrm{Zn}(50$ mol\%), $\mathrm{H}_{2} \mathrm{O}(1.5 \mathrm{~mL})$, temperature as indicated, $\mathrm{H}_{2}$ (30 bar), $15 \mathrm{~h}$; yields of isolated products shown.

$\mathrm{b}$ The reaction time amounted to $40 \mathrm{~h}$.

${ }^{c} \mathrm{Co}(\mathrm{OAc})_{2} \cdot 4 \mathrm{H}_{2} \mathrm{O}(3 \mathrm{~mol} \%)$ and $\mathrm{Zn}(30 \mathrm{~mol} \%)$ were used.

${ }^{\mathrm{d}} \mathrm{Co}(\mathrm{OAC})_{2} \cdot 4 \mathrm{H}_{2} \mathrm{O}(8 \mathrm{~mol} \%)$ and $\mathrm{Zn}(80 \mathrm{~mol} \%)$ were used.

In conclusion, we introduced a user- and eco-friendly heterogeneous catalytic protocol for the hydrogenation of quinolines to yield the corresponding 1,2,3,4-tetrahydroquinolines, some of which are precursors to important biologically active compounds. The method dispenses with the need of any ligands and the selectivity of the given catalytic transformation is readily tuned by way of proper variation of the catalyst loadings and/or the physical reaction parameters. Apart from quinolines, selected $\mathrm{N}$ - and O-heterocycles, but not thiophene, are also amenable to hydrogenation mediated by the reported catalytic system.
All chemicals were purchased from Merck (including Sigma-Aldrich), Fluorochem, Acros Organics, Alfa Aesar, BLDPharm, VWR, Roth, TCI, or Chem Lab, whereby all compounds were used as received without further purification. The catalytic hydrogenation reactions were carried out in a $300 \mathrm{~mL}$ steel autoclave from Parr Instrument $\mathrm{GmbH}$, while the employed hydrogen was purchased from Linde Gas $\mathrm{GmbH}$ with a purity of 5.0. Routine GC-MS analyses were carried out on a Shimadzu GC-MS QP-2020 instrument with helium (5.0 purity from Linde Gas $\mathrm{GmbH}$ ) as carrier gas. HRMS measurements were performed on an Agilent QTOF 6520 instrument. IR spectroscopy was performed on a Bruker Alpha II spectrophotometer. Melting points were determined on a Büchi M-560 device. NMR measurements were performed on a Bruker Avance III $300 \mathrm{MHz}\left(300 \mathrm{MHz}\right.$ for ${ }^{1} \mathrm{H}, 75.5 \mathrm{MHz}$ for ${ }^{13} \mathrm{C}$ ) or $500 \mathrm{MHz}\left(470.5 \mathrm{MHz}\right.$ for $\left.{ }^{19} \mathrm{~F}\right)$ spectrometer. Chemical shifts $\delta$ in ppm were calibrated by using the residual nondeuterated solvents as reference for the ${ }^{1} \mathrm{H}$ and ${ }^{13} \mathrm{C}$ NMR spectra.

\section{Quinolines 1u,v by Suzuki-Miyaura Cross-Coupling Reaction; General Procedure}

The synthesis was performed in accordance with a published literature protocol. ${ }^{52}$ An oven-dried Schlenk tube was charged with the aryl halide $(3.0 \mathrm{mmol})$ and the boronic acid $(3.3 \mathrm{mmol})$, followed by addition of a $4 \mathrm{M}$ solution of $\mathrm{Na}_{2} \mathrm{CO}_{3}$ in degassed $\mathrm{H}_{2} \mathrm{O}(1.5 \mathrm{~mL}, 6$ $\mathrm{mmol})$. Thereafter, the mixture was taken up in degassed THF $(6 \mathrm{~mL})$ and $\mathrm{Pd}\left(\mathrm{PPh}_{3}\right)_{4}(103 \mathrm{mg}, 0.089 \mathrm{mmol})$ was added before sealing the tube and stirring the solution at $80^{\circ} \mathrm{C}$ for $15 \mathrm{~h}$ under an argon atmosphere. The mixture was then allowed to reach rt upon which it was diluted with $\mathrm{H}_{2} \mathrm{O}$ ( $5 \mathrm{~mL}$ ). The quenched solution was extracted thrice with EtOAc $(3 \times)$, after which the combined organic layers were washed with brine and dried with $\mathrm{Na}_{2} \mathrm{SO}_{4}$. Subsequent removal of the volatiles under reduced pressure afforded the crude product, which was eventually purified by column chromatography.

\section{6-(Naphthalen-1-yl)quinoline (1u)}

6-Bromoquinoline (624 mg, $3.0 \mathrm{mmol}$ ) and 1-naphthalenylboronic acid (569 mg, $3.3 \mathrm{mmol}$ ) were used following the standard procedure. The crude product appeared as a brown oil and was purified by column chromatography (silica gel, heptane/EtOAc 1:1).

Yield: $601 \mathrm{mg}$ (2.4 mmol, 78\%); pale-yellow oil.

IR (KBr): 3043, 1589, 1495, 1394, 1371, 1121, $776 \mathrm{~cm}^{-1}$.

${ }^{1} \mathrm{H}$ NMR $\left(300 \mathrm{MHz}, \mathrm{CDCl}_{3}, 20{ }^{\circ} \mathrm{C}\right): \delta=8.98(\mathrm{dd}, J=4.2,1.7 \mathrm{~Hz}, 1 \mathrm{H}, \mathrm{Ar}-$ H), 8.26-8.19 (m, 2 H, Ar-H), 7.98-7.85 (m, $5 \mathrm{H}, \mathrm{Ar}-\mathrm{H}), 7.61-7.41(\mathrm{~m}$, $5 \mathrm{H}, \mathrm{Ar}-\mathrm{H})$.

${ }^{13} \mathrm{C}$ NMR $\left(75.5 \mathrm{MHz}, \mathrm{CDCl}_{3}, 20{ }^{\circ} \mathrm{C}\right): \delta=150.6,147.6,139.3,139.2$, 136.2, 133.8, 132.1, 131.6, 129.2, 128.5, 128.4, 128.3, 128.1, 127.4, 126.3, 126.0, 125.8, 125.4, 121.5 .

HRMS (ESI): $m / z[\mathrm{M}+\mathrm{H}]^{+}$calcd for $\mathrm{C}_{19} \mathrm{H}_{14} \mathrm{~N}$ : 256.11208; found: 256.11267.

\section{3-(Isoquinolin-1-yl)quinoline (1v)}

1-Chloroisoquinoline $(501 \mathrm{mg}, 3.06 \mathrm{mmol}$ ) and 3-quinolinylboronic acid (571 mg, $3.30 \mathrm{mmol}$ ) were used, following the general procedure. The crude product appeared as a brown oil and was purified by column chromatography (silica gel, heptane/EtOAc 1:1).

Yield: 695 mg (2.7 mmol, 89\%); white amorphous powder; mp 93-91 ${ }^{\circ} \mathrm{C}$.

IR (KBr): 3055, 1618, 1533, 1492, 1389, 1313, 837, 747, $677 \mathrm{~cm}^{-1}$. 
${ }^{1} \mathrm{H}$ NMR $\left(300 \mathrm{MHz}, \mathrm{CDCl}_{3}, 20{ }^{\circ} \mathrm{C}\right): \delta=9.29(\mathrm{~d}, J=2.2 \mathrm{~Hz}, 1 \mathrm{H}, \mathrm{Ar}-\mathrm{H})$, $8.69(\mathrm{~d}, J=5.7 \mathrm{~Hz}, 1 \mathrm{H}, \mathrm{Ar}-\mathrm{H}), 8.53(\mathrm{~d}, J=2.0 \mathrm{~Hz}, 1 \mathrm{H}, \mathrm{Ar}-\mathrm{H}) 8.23(\mathrm{~d}, J=$ $8.5 \mathrm{~Hz}, 1 \mathrm{H}, \mathrm{Ar}-\mathrm{H}), 8.11(\mathrm{~d}, J=8.4 \mathrm{~Hz}, 1 \mathrm{H}, \mathrm{Ar}-\mathrm{H}), 7.98-7.91(\mathrm{~m}, 2 \mathrm{H}, \mathrm{Ar}-$ H), 7.85-7.70 (m, $3 \mathrm{H}, \mathrm{Ar}-\mathrm{H})$, 7.66-7.56 (m, $2 \mathrm{H}, \mathrm{Ar}-\mathrm{H})$.

${ }^{13} \mathrm{C}$ NMR $\left(75.5 \mathrm{MHz}, \mathrm{CDCl}_{3}, 20{ }^{\circ} \mathrm{C}\right): \delta=157.6,151.4,148.1,142.7$, $137.2,137.1,132.7,130.5,130.3,129.6,128.4,128.0,127.7,127.4$, 127.3, 127.1, 127.0, 120.7 .

HRMS (ESI): $m / z[M+H]^{+}$calcd for $\mathrm{C}_{18} \mathrm{H}_{13} \mathrm{~N}_{2}:$ 257.10732; found: 257.10771

\section{Tetrahydroquinolines 2 by Catalytic Hydrogenation; General Procedure}

Without any protection from air, a $4 \mathrm{~mL}$ glass vial was initially charged with a magnetic stirring bar, the cobalt(II) salt (0.0125-0.04 $\mathrm{mmol}$ ), and finely powdered $\mathrm{Zn}$ metal $(0.075-0.4 \mathrm{mmol})$. After that, 1 $(0.5 \mathrm{mmol})$ and the solvent $(1.5 \mathrm{~mL})$ were added. The vial was then sealed with a septum cap, which was subsequently penetrated with a steel cannula. The thus-prepared reaction vessel was then placed in a drilled Al-plate with a capacity to accommodate seven vials. Hereafter, this Al-inlay was transferred into the pressure tank which was then tightly sealed. The autoclave was then flushed with $\mathrm{H}_{2}$ gas $(3 \times$ $30 \mathrm{bar}$ ) before being pressurized to the required value. After that, the autoclave was put on a stirring plate and heated to the required reaction temperature. On completion of the reaction, the autoclave was allowed to reach $\mathrm{rt}$, upon which the $\mathrm{H}_{2}$ pressure was released. Chlorobenzene $(20 \mathrm{mg})$ served as a standard and was added to each of the reaction vials, followed by $\mathrm{EtOH}(2 \mathrm{~mL})$ to ensure homogeneity of the reaction mixture. Thereafter, the solutions were degassed by gentle stirring in air for a period of $10 \mathrm{~min}$, upon which an aliquot of $40 \mu \mathrm{L}$ was taken from each vial; EtOH $(0.5 \mathrm{~mL})$ was added and the solutions were eventually analyzed by GC. In cases where the product was isolated, no standard was added in order not to compromise the purification process.

Procedure A: $\mathrm{Co}(\mathrm{OAc})_{2} \cdot 4 \mathrm{H}_{2} \mathrm{O}(3.1 \mathrm{mg}, 0.0125 \mathrm{mmol}, 2.5 \mathrm{~mol} \%)$ and $\mathrm{Zn}$ (8.2, $0.125 \mathrm{mmol}, 25 \mathrm{~mol} \%)$ were used.

Procedure B: $\mathrm{Co}(\mathrm{OAc})_{2} \cdot 4 \mathrm{H}_{2} \mathrm{O}(6.2 \mathrm{mg}, 0.025 \mathrm{mmol}, 5 \mathrm{~mol} \%)$ and $\mathrm{Zn}$ (16.3 mg, $0.25 \mathrm{mmol}, 50 \mathrm{~mol} \%$ ) were used.

Procedure C: $\mathrm{Co}(\mathrm{OAc})_{2} \cdot 4 \mathrm{H}_{2} \mathrm{O}(6.2 \mathrm{mg}, 0.025 \mathrm{mmol}, 5 \mathrm{~mol} \%)$ and $\mathrm{Zn} \mathrm{(4.9}$ $\mathrm{mg}, 0.075 \mathrm{mmol}, 15 \mathrm{~mol} \%)$ were used.

\section{Isolation of the Hydrogenation Products 2; General Procedure}

The aqueous-ethanolic product solution was transferred to a $25 \mathrm{~mL}$ round-bottomed flask whereupon EtOAc $(5 \mathrm{~mL})$ was added. The $\mathrm{H}_{2} \mathrm{O}$ was removed from the mixture upon addition of solid anhydrous $\mathrm{Na}_{2} \mathrm{SO}_{4}$. After that, the suspension was filtered over a plug of cotton to remove all solids from the mixture. Importantly, the finely dispersed catalyst particles were trapped within the $\mathrm{Na}_{2} \mathrm{SO}_{4}$ slurry and therefore the former were separated concurrently with the desiccation step. The volatiles were then removed under reduced pressure, leaving behind the product either as a solid or an oily substance. If incomplete conversion or side-product formation was observed, subsequent purification by column chromatography (silica gel) afforded the pure product.

\section{Scale-up Experiment}

A $100 \mathrm{~mL}$ baker was charged with a magnetic stirring bar, $\mathrm{Co}(\mathrm{OAc})_{2} \cdot 4 \mathrm{H}_{2} \mathrm{O}(0.25 \mathrm{mmol})$, and finely powdered $\mathrm{Zn}$ metal $(2.5$ mmol), after which quinoline $(\mathbf{1 a} ; 10 \mathrm{mmol})$ and $\mathrm{H}_{2} \mathrm{O}(40 \mathrm{~mL})$ were added. The baker was covered with $\mathrm{Al}$ foil, that was subsequently penetrated with three steel pins. The thus-prepared reaction vessel was then transferred into the autoclave which was then tightly sealed. The autoclave was then flushed with $\mathrm{H}_{2}$ gas ( $3 \times 30$ bar) before being pressurized to 30 bar $\mathrm{H}_{2}$. After that, the autoclave was placed on a stirring plate and heated to $70{ }^{\circ} \mathrm{C}$. After $15 \mathrm{~h}$, the autoclave was allowed to reach $\mathrm{rt}$, at which the remaining $\mathrm{H}_{2}$ gas was released. Thereafter, the reaction mixture was degassed by gently stirring in air for a period of $10 \mathrm{~min}$. Then the two-phase mixture was transferred into a separating funnel, where the product was extracted with EtOAc (3x). The combined organic layers were dried over $\mathrm{Na}_{2} \mathrm{SO}_{4}$ and then the solvent was removed in vacuo, leaving behind product $\mathbf{2 a}$ as a yellow oil; yield: $96 \%$.

\section{Safety Statement Concerning High-Pressure Hydrogenation}

The $\mathrm{H}_{2}$ pressure steel cylinder (200 bar, $50 \mathrm{~L}$ ) was placed in a safety storage cabinet equipped with an installed tapping unit while the gas container was connected to a control panel that allowed for fine adjustment of the $\mathrm{H}_{2}$ pressure used for the hydrogenation reactions. The autoclave charging procedure was performed in a fume hood that was equipped with a sensor that was wired to a magnetic valve. The latter instantaneously stops the gas supply in case of any $\mathrm{H}_{2}$ leakage that might occur during the filling procedure. Furthermore, both optical and acoustic alarm signals are triggered whenever free flammable gas is detected inside the hood.

\section{1,2,3,4-Tetrahydroquinoline (2a)}

The title compound was synthesized according to procedure A from 1a (63.6 mg, $0.49 \mathrm{mmol}$ ).

Yield: $63.0 \mathrm{mg}$ ( $0.47 \mathrm{mmol}, 96 \%)$; pale yellow oil, turns brown in air. IR (KBr): 3403, 2925, 2839, 1605, 1495, 1309, $742 \mathrm{~cm}^{-1}$.

${ }^{1} \mathrm{H}$ NMR $\left(300 \mathrm{MHz}, \mathrm{CDCl}_{3}, 20{ }^{\circ} \mathrm{C}\right): \delta=7.06-6.97(\mathrm{~m}, 2 \mathrm{H}, \mathrm{Ar}-\mathrm{H}), 6.67(\mathrm{t}$, $J=7.3 \mathrm{~Hz}, 1 \mathrm{H}, \mathrm{Ar}-\mathrm{H}), 6.52(\mathrm{~d}, J=7.9 \mathrm{~Hz}, 1 \mathrm{H}, \mathrm{Ar}-\mathrm{H}), 3.85(\mathrm{~s}, 1 \mathrm{H}, \mathrm{N}-\mathrm{H})$, $3.34\left(\mathrm{t}, J=5.5 \mathrm{~Hz}, 2 \mathrm{H}, \mathrm{CH}_{2}\right), 2.82\left(\mathrm{t}, J=6.4 \mathrm{~Hz}, 2 \mathrm{H}, \mathrm{CH}_{2}\right), 2.04-1.93(\mathrm{~m}$, $\left.2 \mathrm{H}, \mathrm{CH}_{2}\right)$.

${ }^{13} \mathrm{C}$ NMR $\left(75.5 \mathrm{MHz}, \mathrm{CDCl}_{3}, 20{ }^{\circ} \mathrm{C}\right): \delta=144.8,129.6,126.8,121.5$, $117.0,114.2,42.0,27.0,22.2$.

HRMS (ESI): $m / z[\mathrm{M}+\mathrm{H}]^{+}$calcd for $\mathrm{C}_{9} \mathrm{H}_{12} \mathrm{~N}$ : 134.09643; found: 134.09630.

\section{2-Methyl-1,2,3,4-tetrahydroquinoline (2b)}

The title compound was synthesized according to procedure A from 1b (70.8 mg, $0.49 \mathrm{mmol}$ ).

Yield: $67.0 \mathrm{mg}$ (0.46 mmol, 92\%); yellow oil, turns brown in air.

IR (KBr): 3390, 2961, 2923, 2843, 1607, 1486, 1307, $742 \mathrm{~cm}^{-1}$.

${ }^{1} \mathrm{H}$ NMR $\left(300 \mathrm{MHz}, \mathrm{CDCl}_{3}, 20{ }^{\circ} \mathrm{C}\right): \delta=7.07-6.99(\mathrm{~m}, 2 \mathrm{H}, \mathrm{Ar}-\mathrm{H}), 6.68$ (td, $J=7.3,0.8 \mathrm{~Hz}, 1 \mathrm{H}, \mathrm{Ar}-\mathrm{H}), 6.56-6.50(\mathrm{~m}, 1 \mathrm{H}, \mathrm{Ar}-\mathrm{H}) 3.77(\mathrm{~s}, 1 \mathrm{H}, \mathrm{N}-$ $\mathrm{H}), 3.52-3.39(\mathrm{~m}, 1 \mathrm{H}, \mathrm{CH}), 2.99-2.74\left(\mathrm{~m}, 2 \mathrm{H}, \mathrm{CH}_{2}\right), 2.05-1.93(\mathrm{~m}, 1 \mathrm{H}$, $\left.\mathrm{CH}_{2}\right), 1.73-1.58\left(\mathrm{~m}, 1 \mathrm{H}, \mathrm{CH}_{2}\right), 1.27\left(\mathrm{~d}, J=6.3 \mathrm{~Hz}, 3 \mathrm{H}, \mathrm{CH}_{3}\right)$.

${ }^{13} \mathrm{C}$ NMR $\left(75.5 \mathrm{MHz}, \mathrm{CDCl}_{3}, 20{ }^{\circ} \mathrm{C}\right): \delta=144.8,129.3,126.7,121.1$, 117.0, 114.1, 47.2, 30.2, 26.6, 22.6 .

HRMS (ESI): $m / z[M+H]^{+}$calcd for $\mathrm{C}_{10} \mathrm{H}_{14} \mathrm{~N}: 148.11208$; found: 148.11219.

\section{3-Methyl-1,2,3,4-tetrahydroquinoline (2c)}

The title compound was synthesized according to procedure B from 1c $(78.1 \mathrm{mg}, 0.55 \mathrm{mmol})$ and then purified by column chromatography (silica gel, heptane/EtOAc 20:1).

Yield: $65.2 \mathrm{mg}$ ( $0.44 \mathrm{mmol}, 81 \%)$; colorless oil, turns brown in air. 
IR (KBr): 3407, 2952, 2912, 2831, 1606, 1493, 1281, $742 \mathrm{~cm}^{-1}$ ${ }^{1} \mathrm{H}$ NMR $\left(300 \mathrm{MHz}, \mathrm{CDCl}_{3}, 20{ }^{\circ} \mathrm{C}\right): \delta=7.06-6.96(\mathrm{~m}, 2 \mathrm{H}, \mathrm{Ar}-\mathrm{H}), 6.66$ $(\mathrm{td}, J=7.3,0.8 \mathrm{~Hz}, 1 \mathrm{H}, \mathrm{Ar}-\mathrm{H}), 6.52(\mathrm{~d}, J=7.8 \mathrm{~Hz}, 1 \mathrm{H}, \mathrm{Ar}-\mathrm{H}) 3.85(\mathrm{~s}, 1 \mathrm{H}$, $\mathrm{N}-\mathrm{H}), 3.36-3.24\left(\mathrm{~m}, 1 \mathrm{H}, \mathrm{CH}_{2}\right), 2.99-2.88\left(\mathrm{~m}, 1 \mathrm{H}, \mathrm{CH}_{2}\right), 2.88-2.77(\mathrm{~m}$, $\left.1 \mathrm{H}, \mathrm{CH}_{2}\right), 2.55-2.71\left(\mathrm{~m}, 1 \mathrm{H}, \mathrm{CH}_{2}\right), 2.20-2.01(\mathrm{~m}, 1 \mathrm{H}, \mathrm{CH}), 1.10(\mathrm{~d}, J=$ $\left.6.6 \mathrm{~Hz}, 3 \mathrm{H}, \mathrm{CH}_{3}\right)$.

${ }^{13} \mathrm{C}$ NMR $\left(75.5 \mathrm{MHz}, \mathrm{CDCl}_{3}, 20{ }^{\circ} \mathrm{C}\right): \delta=144.4,129.6,126.8,121.1$, $116.9,113.9,48.0,35.5,27.2,19.1$.

HRMS (ESI): $m / z[M+\mathrm{H}]^{+}$calcd for $\mathrm{C}_{10} \mathrm{H}_{14} \mathrm{~N}$ : 148.11208; found: 148.11214.

\section{4-Methyl-1,2,3,4-tetrahydroquinoline (2d)}

The title compound was synthesized according to procedure B from 1d $(72.6 \mathrm{mg}, 0.51 \mathrm{mmol})$ and then purified by column chromatography (silica gel, heptane/EtOAc 10:1, 2\% triethylamine).

Yield: $41.6 \mathrm{mg}$ ( $0.28 \mathrm{mmol}, 56 \%)$; colorless oil, turns brown in air.

IR (KBr): 3405, 2955, 2923, 2852, 1605, 1497, 1313, $740 \mathrm{~cm}^{-1}$.

${ }^{1} \mathrm{H}$ NMR $\left(300 \mathrm{MHz}, \mathrm{CDCl}_{3}, 20{ }^{\circ} \mathrm{C}\right): \delta=7.12-7.05(\mathrm{~m}, 1 \mathrm{H}, \mathrm{Ar}-\mathrm{H}), 7.03-$ $6.95(\mathrm{~m}, 1 \mathrm{H}, \mathrm{Ar}-\mathrm{H}), 6.66(\mathrm{td}, J=7.4,1.2 \mathrm{~Hz}, 1 \mathrm{H}, \mathrm{Ar}-\mathrm{H}), 6.50$ (dd, $J=8.0$, $1.1 \mathrm{~Hz}, 1 \mathrm{H}, \mathrm{Ar}-\mathrm{H}), 3.86(\mathrm{~s}, 1 \mathrm{H}, \mathrm{N}-\mathrm{H}), 3.41-3.24\left(\mathrm{~m}, 2 \mathrm{H}, \mathrm{CH}_{2}\right) 2.94$ (sext, $J=6.3 \mathrm{~Hz}, 1 \mathrm{H}, \mathrm{CH}), 2.08-1.94\left(\mathrm{~m}, 1 \mathrm{H}, \mathrm{CH}_{2}\right), 1.77-1.64(\mathrm{~m}, 1 \mathrm{H}$, $\left.\mathrm{CH}_{2}\right), 1.32\left(\mathrm{~d}, J=7.0 \mathrm{~Hz}, 3 \mathrm{H}, \mathrm{CH}_{3}\right)$.

${ }^{13} \mathrm{C}$ NMR $\left(75.5 \mathrm{MHz}, \mathrm{CDCl}_{3}, 20{ }^{\circ} \mathrm{C}\right): \delta=144.3,128.5,126.8,126.7$, 117.0, 114.2, 39.1, 30.3, 30.0, 22.7.

HRMS (ESI): $m / z[\mathrm{M}+\mathrm{H}]^{+}$calcd for $\mathrm{C}_{10} \mathrm{H}_{14} \mathrm{~N}$ : 148.11208; found: 148.11204.

\section{4-Methyl-5,6,7,8-tetrahydroquinoline (2d')}

Synthesized according to procedure B from 1d $(72.6 \mathrm{mg}, 0.507 \mathrm{mmol})$ and purified by column chromatography (silica gel, heptane/EtOAc $1: 1,2 \%$ triethylamine).

Yield: $17.8 \mathrm{mg}$ ( $0.12 \mathrm{mmol}, 24 \%)$; colorless oil, turns brown in air.

IR (KBr): 3379, 2930, 2858, 1587, 1435, $824 \mathrm{~cm}^{-1}$.

${ }^{1} \mathrm{H}$ NMR $\left(300 \mathrm{MHz}, \mathrm{CDCl}_{3}, 20{ }^{\circ} \mathrm{C}\right): \delta=8.21(\mathrm{~d}, J=4.8 \mathrm{~Hz}, 1 \mathrm{H}, \mathrm{Ar}-\mathrm{H})$, $6.88(\mathrm{~d}, J=4.8 \mathrm{~Hz}, 1 \mathrm{H}, \mathrm{Ar}-\mathrm{H}), 2.96-2.85\left(\mathrm{~m}, 2 \mathrm{H}, \mathrm{CH}_{2}\right), 2.68-2.57(\mathrm{~m}, 2$ $\left.\mathrm{H}, \mathrm{CH}_{2}\right), 2.20\left(\mathrm{~s}, 3 \mathrm{H}, \mathrm{CH}_{3}\right), 1.91-1.78\left(\mathrm{~m}, 4 \mathrm{H}, \mathrm{CH}_{2}\right)$.

${ }^{13} \mathrm{C}$ NMR $\left(75.5 \mathrm{MHz}, \mathrm{CDCl}_{3}, 20{ }^{\circ} \mathrm{C}\right): \delta=156.8,146.3,145.8,131.2$, 122.7, 33.1, 25.9, 23.0, 23.0, 19.0 .

HRMS (ESI): $m / z[M+H]^{+}$calcd for $\mathrm{C}_{10} \mathrm{H}_{14} \mathrm{~N}$ : 148.11208; found: 148.11204.

\section{6-Methyl-1,2,3,4-tetrahydroquinoline (2e)}

The title compound was prepared according to procedure A from $\mathbf{1 e}$ (71.2 $\mathrm{mg}, 0.497 \mathrm{mmol}$ ).

Yield: $70.0 \mathrm{mg}$ (0.48 mmol, 96\%); yellow oil, turns brown in air.

IR (KBr): 3397, 2922, 2840, 1619, 1500, 1301, $806 \mathrm{~cm}^{-1}$.

${ }^{1} \mathrm{H}$ NMR $\left(300 \mathrm{MHz}, \mathrm{CDCl}_{3}, 2{ }^{\circ} \mathrm{C}\right): \delta=6.88-6.77(\mathrm{~m}, 2 \mathrm{H}, \mathrm{Ar}-\mathrm{H}), 6.46(\mathrm{~d}$, $J=8.5 \mathrm{~Hz}, 1 \mathrm{H}, \mathrm{Ar}-\mathrm{H}), 3.71(\mathrm{~s}, 1 \mathrm{H}, \mathrm{N}-\mathrm{H}), 3.31\left(\mathrm{t}, J=5.3 \mathrm{~Hz}, 2 \mathrm{H}, \mathrm{CH}_{2}\right)$, $2.79\left(\mathrm{t}, J=6.4 \mathrm{~Hz}, 2 \mathrm{H}, \mathrm{CH}_{2}\right), 2.27\left(\mathrm{~s}, 3 \mathrm{H}, \mathrm{CH}_{3}\right), 1.98$ (quint, $J=5.7 \mathrm{~Hz}, 2$ $\mathrm{H}, \mathrm{CH}_{2}$ ).

${ }^{13} \mathrm{C}$ NMR $\left(75.5 \mathrm{MHz}, \mathrm{CDCl}_{3}, 20{ }^{\circ} \mathrm{C}\right): \delta=142.5,130.1,127.3,126.3$, 121.6, 114.5, 42.2, 27.0, 22.5, 20.5.

HRMS (ESI): $m / z[M+H]^{+}$calcd for $\mathrm{C}_{10} \mathrm{H}_{14} \mathrm{~N}$ : 148.11208; found: 148.11225 .

\section{7-Methyl-1,2,3,4-tetrahydroquinoline (2f)}

The title compound was synthesized according to procedure B from $\mathbf{1 f}$ (70.5 mg, $0.49 \mathrm{mmol}$ ).

Yield: $69.3 \mathrm{mg}$ ( $0.47 \mathrm{mmol}, 96 \%)$; yellow oil, turns brown in air. IR (KBr): 3399, 2922, 2840, 1618, 1489, 1309, $788 \mathrm{~cm}^{-1}$.

${ }^{1} \mathrm{H}$ NMR $\left(300 \mathrm{MHz}, \mathrm{CDCl}_{3}, 20{ }^{\circ} \mathrm{C}\right): \delta=6.91(\mathrm{~d}, J=7.6 \mathrm{~Hz}, 1 \mathrm{H}, \mathrm{Ar}-\mathrm{H})$, $6.51(\mathrm{~d}, J=7.8 \mathrm{~Hz}, 1 \mathrm{H}, \mathrm{Ar}-\mathrm{H}), 6.37(\mathrm{~s}, 1 \mathrm{H}, \mathrm{Ar}-\mathrm{H}), 3.75(\mathrm{~s}, 1 \mathrm{H}, \mathrm{N}-\mathrm{H})$, $3.34\left(\mathrm{t}, J=5.5 \mathrm{~Hz}, 2 \mathrm{H}, \mathrm{CH}_{2}\right) 2.80\left(\mathrm{t}, J=6.4 \mathrm{~Hz}, 2 \mathrm{H}, \mathrm{CH}_{2}\right), 2.30(\mathrm{~s}, 3 \mathrm{H}$, $\left.\mathrm{CH}_{3}\right), 2.05-1.94\left(\mathrm{~m}, 2 \mathrm{H}, \mathrm{CH}_{2}\right)$.

${ }^{13} \mathrm{C}$ NMR $\left(75.5 \mathrm{MHz}, \mathrm{CDCl}_{3}, 20{ }^{\circ} \mathrm{C}\right): \delta=144.6,136.4,129.4,118.6$, 117.9, 114.8, 42.1, 26.7, 22.4, 21.2.

HRMS (ESI): $m / z[M+\mathrm{H}]^{+}$calcd for $\mathrm{C}_{10} \mathrm{H}_{14} \mathrm{~N}$ : 148.11208; found: 148.11241.

\section{8-Methyl-1,2,3,4-tetrahydroquinoline (2g)}

The title compound was prepared according to procedure B from $\mathbf{1 g}$ (701.7 mg, $0.50 \mathrm{mmol}$ ).

Yield: $71.3 \mathrm{mg}$ (0.48 mmol, 97\%); yellow oil, turns brown in air.

IR (KBr): 3423, 2925, 2841, 1598, 1481, 1307, 754, $732 \mathrm{~cm}^{-1}$.

${ }^{1} \mathrm{H}$ NMR $\left(300 \mathrm{MHz}, \mathrm{CDCl}_{3}, 20{ }^{\circ} \mathrm{C}\right): \delta=6.97(\mathrm{t}, J=7.5 \mathrm{~Hz}, 2 \mathrm{H}, \mathrm{Ar}-\mathrm{H})$, $6.67(\mathrm{t}, J=7.4 \mathrm{~Hz}, 1 \mathrm{H}, \mathrm{Ar}-\mathrm{H}), 3.69(\mathrm{~s}, 1 \mathrm{H}, \mathrm{N}-\mathrm{H}), 3.47(\mathrm{t}, J=5.4 \mathrm{~Hz}, 2 \mathrm{H}$, $\mathrm{CH}_{2}$ ), $2.90\left(\mathrm{t}, J=6.3 \mathrm{~Hz}, 2 \mathrm{H}, \mathrm{CH}_{2}\right), 2.18\left(\mathrm{~s}, 3 \mathrm{H}, \mathrm{CH}_{3}\right), 2.05$ (quint, $J=6.0$ $\left.\mathrm{Hz}, 2 \mathrm{H}, \mathrm{CH}_{2}\right)$.

${ }^{13} \mathrm{C}$ NMR $\left(75.5 \mathrm{MHz}, \mathrm{CDCl}_{3}, 20{ }^{\circ} \mathrm{C}\right): \delta=142.7,127.9,127.4,121.2$, $120.9,116.4,42.4,27.3,22.2,17.2$.

HRMS (ESI): $m / z[M+\mathrm{H}]^{+}$calcd for $\mathrm{C}_{10} \mathrm{H}_{14} \mathrm{~N}$ : 148.11208; found: 148.11234 .

\section{3-Methoxy-1,2,3,4-tetrahydroquinoline (2h)}

The title compound was synthesized following procedure B from $\mathbf{1 h}$ ( $80.0 \mathrm{mg}, 0.503 \mathrm{mmol}$ ).

Yield: $79.3 \mathrm{mg}$ (0.49 mmol, 97\%); yellow oil, turns brown in air.

IR (KBr): 3423, 2925, 2841, 1598, 1481, 1307, 754, $732 \mathrm{~cm}^{-1}$.

${ }^{1} \mathrm{H} \mathrm{NMR}\left(300 \mathrm{MHz}, \mathrm{CDCl}_{3}, 20{ }^{\circ} \mathrm{C}\right): \delta=7.07-6.96(\mathrm{~m}, 2 \mathrm{H}, \mathrm{Ar}-\mathrm{H}), 6.68(\mathrm{t}$, $J=7.3 \mathrm{~Hz}, 1 \mathrm{H}, \mathrm{Ar}-\mathrm{H}), 6.53(\mathrm{~d}, J=8.0 \mathrm{~Hz}, 1 \mathrm{H}, \mathrm{Ar}-\mathrm{H}), 3.93-3.72(\mathrm{~m}, 2 \mathrm{H}$, $\mathrm{N}-\mathrm{H}, \mathrm{CH}), 3.53-3.40\left(\mathrm{~m}, 4 \mathrm{H}, \mathrm{CH}_{3}, \mathrm{CH}_{2}\right), 3.23(\mathrm{dd}, J=11.0,7.2 \mathrm{~Hz}, 1 \mathrm{H}$, $\mathrm{CH}_{2}$ ), 3.06 (dd, $\left.J=16.0,4.0 \mathrm{~Hz}, 1 \mathrm{H}, \mathrm{CH}_{2}\right), 2.84(\mathrm{dd}, J=16.0,7.0 \mathrm{~Hz}, 1 \mathrm{H}$, $\mathrm{CH}_{2}$ ).

${ }^{13} \mathrm{C}$ NMR $\left(75.5 \mathrm{MHz}, \mathrm{CDCl}_{3}, 20{ }^{\circ} \mathrm{C}\right): \delta=143.9,130.0,127.0,118.9$, 117.5, 114.0, 72.7, 56.2, 45.2, 32.7.

HRMS (ESI): $m / z[\mathrm{M}+\mathrm{H}]^{+}$calcd for $\mathrm{C}_{10} \mathrm{H}_{14} \mathrm{NO}$ : 164.10699; found: 164.10667.

\section{5-Methoxy-1,2,3,4-tetrahydroquinoline (2i)}

The title compound was prepared following procedure B from $\mathbf{1 i}$ (79.2 $\mathrm{mg}, 0.50 \mathrm{mmol})$.

Yield: $77.3 \mathrm{mg}$ (0.474 mmol, 95\%); pale-yellow oil, turns brown in air. IR (KBr): 3401, 2937, 2835, 1589, 1492, 1346, 1239, 1120, 761, 707 $\mathrm{cm}^{-1}$.

${ }^{1} \mathrm{H}$ NMR $\left(300 \mathrm{MHz}, \mathrm{CDCl}_{3}, 20{ }^{\circ} \mathrm{C}\right): \delta=6.98(\mathrm{t}, J=8.1 \mathrm{~Hz}, 1 \mathrm{H}, \mathrm{Ar}-\mathrm{H})$, $6.23(\mathrm{dd}, J=19.9,8.1 \mathrm{~Hz}, 2 \mathrm{H}, \mathrm{Ar}-\mathrm{H}), 3.84\left(\mathrm{~s}, 4 \mathrm{H}, \mathrm{N}-\mathrm{H}, \mathrm{CH}_{3}\right), 3.28(\mathrm{t}, J=$ $5.3 \mathrm{~Hz}, 2 \mathrm{H}, \mathrm{CH}_{2}$ ), $2.71\left(\mathrm{t}, J=6.5 \mathrm{~Hz}, 2 \mathrm{H}, \mathrm{CH}_{2}\right.$ ), 1.97 (quint, $J=5.9 \mathrm{~Hz}, 2$ $\mathrm{H}, \mathrm{CH}_{2}$ ).

${ }^{13} \mathrm{C}$ NMR $\left(75.5 \mathrm{MHz}, \mathrm{CDCl}_{3}, 20{ }^{\circ} \mathrm{C}\right): \delta=158.0,145.9,126.7,109.8$, 107.7, 99.2, 55.3, 41.6, 22.0, 20.6. 
HRMS (ESI): $m / z[M+\mathrm{H}]^{+}$calcd for $\mathrm{C}_{10} \mathrm{H}_{14} \mathrm{NO}$ : 164.10699; found: 164.10665 .

\section{6-Methoxy-1,2,3,4-tetrahydroquinoline ( $2 \mathrm{j}$ )}

The title compound was synthesized according to procedure B from $\mathbf{1 j}$ (80.0 mg, $0.503 \mathrm{mmol}$ ).

Yield: $81.0 \mathrm{mg}$ ( $0.50 \mathrm{mmol}, 99 \%)$; pale-yellow oil, turns brown in air. IR (KBr): 3387, 2928, 2831, 1503, 1251, 1230, 1037, $804 \mathrm{~cm}^{-1}$.

${ }^{1} \mathrm{H} \mathrm{NMR}\left(300 \mathrm{MHz}, \mathrm{CDCl}_{3}, 20{ }^{\circ} \mathrm{C}\right): \delta=6.66-6.57(\mathrm{~m}, 2 \mathrm{H}, \mathrm{Ar}-\mathrm{H}), 6.47(\mathrm{~d}$, $J=8.4 \mathrm{~Hz}, 1 \mathrm{H}, \mathrm{Ar}-\mathrm{H}), 3.75\left(\mathrm{~s}, 3 \mathrm{H}, \mathrm{CH}_{3}\right), 3.70(\mathrm{~s}, 1 \mathrm{H}, \mathrm{N}-\mathrm{H}), 3.26$ (t, $J=$ $\left.5.5 \mathrm{~Hz}, 2 \mathrm{H}, \mathrm{CH}_{2}\right), 2.78\left(\mathrm{t}, J=6.5 \mathrm{~Hz}, 2 \mathrm{H}, \mathrm{CH}_{2}\right) 2.00-1.90\left(\mathrm{~m}, 2 \mathrm{H}, \mathrm{CH}_{2}\right)$. ${ }^{13} \mathrm{C}$ NMR $\left(75.5 \mathrm{MHz}, \mathrm{CDCl}_{3}, 20{ }^{\circ} \mathrm{C}\right): \delta=151.8,138.9,122.9,115.6$, $114.9,112.9,55.8,42.3,27.2,22.4$.

HRMS (ESI): $m / z[M+H]^{+}$calcd for $\mathrm{C}_{10} \mathrm{H}_{14} \mathrm{NO}$ : 164.10699; found: 164.10678

\section{6-Methoxy-2-methyl-1,2,3,4-tetrahydroquinoline (2k)}

The title compound was synthesized following procedure B from $\mathbf{1 k}$ (85.9 mg, $0.496 \mathrm{mmol}$ ).

Yield: $84.8 \mathrm{mg}$ (0.478 mmol, 96\%); pale-yellow oil, turns brown in air. IR (KBr): 3374, 2928, 2831, 1499, 1236, 1151, 1037, $804 \mathrm{~cm}^{-1}$.

${ }^{1} \mathrm{H} \mathrm{NMR}\left(300 \mathrm{MHz}, \mathrm{CDCl}_{3}, 20{ }^{\circ} \mathrm{C}\right): \delta=6.65-6.57(\mathrm{~m}, 2 \mathrm{H}, \mathrm{Ar}-\mathrm{H}), 6.47(\mathrm{~d}$, $J=8.2 \mathrm{~Hz}, 1 \mathrm{H}, \mathrm{Ar}-\mathrm{H}), 3.75\left(\mathrm{~s}, 3 \mathrm{H}, \mathrm{CH}_{3}\right), 3.58(\mathrm{~s}, 1 \mathrm{H}, \mathrm{N}-\mathrm{H}), 3.42-3.27$ (m, $1 \mathrm{H}, \mathrm{CH}), 3.95-3.79\left(\mathrm{~m}, 1 \mathrm{H}, \mathrm{CH}_{2}\right), 3.79-3.66\left(\mathrm{~m}, 1 \mathrm{H}, \mathrm{CH}_{2}\right), 2.00-$ $1.87\left(\mathrm{~m}, 1 \mathrm{H}, \mathrm{CH}_{2}\right), 1.69-1.51\left(\mathrm{~m}, 1 \mathrm{H}, \mathrm{CH}_{2}\right), 1.21(\mathrm{~d}, J=6.3 \mathrm{~Hz}, 3 \mathrm{H}$, $\left.\mathrm{CH}_{3}\right)$.

${ }^{13} \mathrm{C}$ NMR $\left(75.5 \mathrm{MHz}, \mathrm{CDCl}_{3}, 20{ }^{\circ} \mathrm{C}\right): \delta=151.9,138.9,122.5,115.4$, 114.7, 112.9, 55.8, 47.5, 30.3, 26.9, 22.6 .

HRMS (ESI): $m / z[M+H]^{+}$calcd for $\mathrm{C}_{11} \mathrm{H}_{16} \mathrm{NO}$ : 178.12264; found: 178.12263

\section{6-Fluoro-1,2,3,4-tetrahydroquinoline (21)}

The title compound was synthesized according to procedure B from $\mathbf{1 1}$ (73.7 $\mathrm{mg}, 0.50 \mathrm{mmol}$ ).

Yield: $74.1 \mathrm{mg}$ (0.49 mmol, 98\%); pale-yellow oil, turns brown in air. IR (KBr): 3399, 2929, 2844, 1501, 1247, 1221, 1190, 1140, $804 \mathrm{~cm}^{-1}$. ${ }^{1} \mathrm{H} \mathrm{NMR}\left(300 \mathrm{MHz}, \mathrm{CDCl}_{3}, 20{ }^{\circ} \mathrm{C}\right): \delta=6.75-6.63(\mathrm{~m}, 2 \mathrm{H}, \mathrm{Ar}-\mathrm{H}), 6.40(\mathrm{q}$, $J=4.5 \mathrm{~Hz}, 1 \mathrm{H}, \mathrm{Ar}-\mathrm{H}), 3.70(\mathrm{~s}, 1 \mathrm{H}, \mathrm{N}-\mathrm{H}), 3.27\left(\mathrm{t}, J=5.3 \mathrm{~Hz}, 2 \mathrm{H}, \mathrm{CH}_{2}\right)$, $2.75\left(\mathrm{t}, J=6.2 \mathrm{~Hz}, 2 \mathrm{H}, \mathrm{CH}_{2}\right), 1.93\left(\mathrm{q}, J=5.8 \mathrm{~Hz}, 2 \mathrm{H}, \mathrm{CH}_{2}\right)$.

${ }^{13} \mathrm{C}$ NMR (75.5 MHz, $\left.\mathrm{CDCl}_{3}, 20{ }^{\circ} \mathrm{C}\right): \delta=155.4(\mathrm{~d}, J=234.5 \mathrm{~Hz}, 1 \mathrm{C}), 141.0$ $(\mathrm{d}, J=1.8 \mathrm{~Hz}, 1 \mathrm{C}), 122.8(\mathrm{~d}, J=6.7 \mathrm{~Hz}, 1 \mathrm{C}), 115.6(\mathrm{~d}, J=21.5 \mathrm{~Hz}, 1 \mathrm{C})$, 115.0 (d, $J=7.6 \mathrm{~Hz}, 1 \mathrm{C}), 113.2$ (d, $J=22.4 \mathrm{~Hz}, 1 \mathrm{C}), 42.1,27.1$ (d, $J=0.9$ $\mathrm{Hz}, 1 \mathrm{C}), 22.0$.

${ }^{19} \mathrm{~F}$ NMR (470.5 MHz, $\left.\mathrm{CDCl}_{3}, 20{ }^{\circ} \mathrm{C}\right): \delta=-128.4$.

HRMS (ESI): $m / z[M+H]^{+}$calcd for $\mathrm{C}_{9} \mathrm{H}_{11} \mathrm{FN}$ : 152.08700 ; found: 152.08753.

\section{6-Fluoro-2-methyl-1,2,3,4-tetrahydroquinoline ( $2 \mathrm{~m})$}

The title compound was prepared following procedure B from $1 \mathbf{m}$ (80.5 mg, $0.50 \mathrm{mmol}$ ).

Yield: $75.3 \mathrm{mg}$ ( $0.46 \mathrm{mmol}, 91 \%)$; pale-yellow oil, turns brown in air. IR (KBr): 3397, 2963, 2926, 2847, 1407, 1230, 1141, $803 \mathrm{~cm}^{-1}$.
${ }^{1} \mathrm{H}$ NMR $\left(300 \mathrm{MHz}, \mathrm{CDCl}_{3}, 20{ }^{\circ} \mathrm{C}\right): \delta=6.74-6.64(\mathrm{~m}, 2 \mathrm{H}, \mathrm{Ar}-\mathrm{H}), 6.44-$ 6.37 (m, $1 \mathrm{H}, \mathrm{Ar}-\mathrm{H}), 3.59$ (s, $1 \mathrm{H}, \mathrm{N}-\mathrm{H}), 3.42-3.29$ (m, $1 \mathrm{H}, \mathrm{CH}), 2.91-$ $2.77\left(\mathrm{~m}, 1 \mathrm{H}, \mathrm{CH}_{2}\right), 2.77-2.65\left(\mathrm{~m}, 1 \mathrm{H}, \mathrm{CH}_{2}\right), 1.98-1.86\left(\mathrm{~m}, 1 \mathrm{H}, \mathrm{CH}_{2}\right)$, 1.65-1.47 (m, $\left.1 \mathrm{H}, \mathrm{CH}_{2}\right), 1.21\left(\mathrm{~d}, J=6.2 \mathrm{~Hz}, 3 \mathrm{H}, \mathrm{CH}_{3}\right)$.

${ }^{13} \mathrm{C}$ NMR $\left(75.5 \mathrm{MHz}, \mathrm{CDCl}_{3}, 20{ }^{\circ} \mathrm{C}\right): \delta=155.6(\mathrm{~d}, J=234.4 \mathrm{~Hz}, 1 \mathrm{C}), 141.1$ (d, $J=1.6 \mathrm{~Hz}, 1 \mathrm{C}), 122.6$ (d, $J=6.7 \mathrm{~Hz}, 1 \mathrm{C}), 115.5$ (d, $J=21.6 \mathrm{~Hz}, 1 \mathrm{C}$ ), 114.8 (d, $J=7.5 \mathrm{~Hz}, 1 \mathrm{C}), 113.3(\mathrm{~d}, J=22.4 \mathrm{~Hz}, 1 \mathrm{C}), 47.4,30.0,26.8$ (d, $J=1.1 \mathrm{~Hz}, 1 \mathrm{C}), 22.6$.

${ }^{19} \mathrm{~F}$ NMR $\left(470.5 \mathrm{MHz}, \mathrm{CDCl}_{3}, 20{ }^{\circ} \mathrm{C}\right): \delta=-128.3$.

HRMS (ESI): $m / z[\mathrm{M}+\mathrm{H}]^{+}$calcd for $\mathrm{C}_{10} \mathrm{H}_{13} \mathrm{FN}$ : 166.10265; found: 166.10268.

\section{8-Fluoro-1,2,3,4-tetrahydroquinoline (2n)}

The title compound was synthesized according to procedure A from 1n $(75.8 \mathrm{mg}, 0.52 \mathrm{mmol})$.

Yield: $70.9 \mathrm{mg}$ (0.469 mmol, 91\%); pale-yellow oil, turns brown in air. IR (KBr): 3424, 2929, 2841, 1624, 1499, 1316, 1232, 758, $719 \mathrm{~cm}^{-1}$.

${ }^{1} \mathrm{H}$ NMR $\left(300 \mathrm{MHz}, \mathrm{CDCl}_{3}, 20{ }^{\circ} \mathrm{C}\right): \delta=6.89-6.73(\mathrm{~m}, 2 \mathrm{H}, \mathrm{Ar}-\mathrm{H}), 6.59-$ $6.47(\mathrm{~m}, 1 \mathrm{H}, \mathrm{Ar}-\mathrm{H}), 4.00(\mathrm{~s}, 1 \mathrm{H}, \mathrm{N}-\mathrm{H}), 3.36\left(\mathrm{t}, J=5.5 \mathrm{~Hz}, 2 \mathrm{H}, \mathrm{CH}_{2}\right)$, $2.81\left(\mathrm{t}, J=6.4 \mathrm{~Hz}, 2 \mathrm{H}, \mathrm{CH}_{2}\right), 2.04-1.93\left(\mathrm{~m}, 2 \mathrm{H}, \mathrm{CH}_{2}\right)$.

${ }^{13} \mathrm{C} \mathrm{NMR}\left(75.5 \mathrm{MHz}, \mathrm{CDCl}_{3}, 20{ }^{\circ} \mathrm{C}\right): \delta=160.0(\mathrm{~d}, J=237.7 \mathrm{~Hz}, 1 \mathrm{C}), 133.3$ (d, $J=12.2 \mathrm{~Hz}, 1 \mathrm{C}), 124.6$ (d, $J=2.9 \mathrm{~Hz}, 1 \mathrm{C}), 123.7(\mathrm{~d}, J=3.8 \mathrm{~Hz}, 1 \mathrm{C})$, 115.6 (d, $J=7.5 \mathrm{~Hz}, 1 \mathrm{C}), 112.2$ (d, $J=18.2 \mathrm{~Hz}, 1 \mathrm{C}), 41.3,26.6$ (d, $J=3.1$ $\mathrm{Hz}, 1 \mathrm{C}), 21.9$.

${ }^{19} \mathrm{~F}$ NMR $\left(470.5 \mathrm{MHz}, \mathrm{CDCl}_{3}, 20{ }^{\circ} \mathrm{C}\right): \delta=-139.0$

HRMS (ESI): $m / z[M+H]^{+}$calcd for $\mathrm{C}_{9} \mathrm{H}_{11} \mathrm{FN}$ : 152.08700 ; found: 152.08810 .

\section{5-Chloro-1,2,3,4-tetrahydroquinoline (2o)}

The title compound was synthesized according to procedure B from 10 ( $80.7 \mathrm{mg}, 0.49 \mathrm{mmol}$ ) and then purified by column chromatography (silica gel, heptane/DCM, 10:1).

Yield: $41.8 \mathrm{mg}$ ( $0.25 \mathrm{mmol}, 51 \%)$; colorless oil, turns brown in air. IR (KBr): 3414, 2947, 2928, 2856, 2840, 1596, 1487, 1303, $761 \mathrm{~cm}^{-1}$. ${ }^{1} \mathrm{H}$ NMR $\left(300 \mathrm{MHz}, \mathrm{CDCl}_{3}, 20{ }^{\circ} \mathrm{C}\right): \delta=6.87(\mathrm{t}, J=7.9 \mathrm{~Hz}, 1 \mathrm{H}, \mathrm{Ar}-\mathrm{H})$, $6.67(\mathrm{dd}, J=7.9,1.0 \mathrm{~Hz}, 1 \mathrm{H}, \mathrm{Ar}-\mathrm{H}), 6.36(\mathrm{dd}, J=8.0,1.0 \mathrm{~Hz}, 1 \mathrm{H}, \mathrm{Ar}-\mathrm{H}$ ), $3.94(\mathrm{~s}, 1 \mathrm{H}, \mathrm{N}-\mathrm{H}), 3.26\left(\mathrm{t}, J=5.5 \mathrm{~Hz}, 2 \mathrm{H}, \mathrm{CH}_{2}\right), 2.78(\mathrm{t}, J=6.6 \mathrm{~Hz}, 2 \mathrm{H}$, $\left.\mathrm{CH}_{2}\right), 2.02-1.90\left(\mathrm{~m}, 2 \mathrm{H}, \mathrm{CH}_{2}\right)$.

${ }^{13} \mathrm{C}$ NMR $\left(75.5 \mathrm{MHz}, \mathrm{CDCl}_{3}, 20{ }^{\circ} \mathrm{C}\right): \delta=146.5,135.0,127.2,119.4$, 117.6, 112.6, 41.5, 24.8, 22.0.

HRMS (ESI): $m / z[M+H]^{+}$calcd for $\mathrm{C}_{9} \mathrm{H}_{11} \mathrm{ClN}$ : 168.05745 ; found: 168.05775 .

\section{6-Chloro-1,2,3,4-tetrahydroquinoline (2p)}

The title compound was synthesized according to procedure $C$ from 1 p ( $81.5 \mathrm{mg}, 0.498 \mathrm{mmol})$ and then purified by column chromatography (silica gel, heptane/EtOAc 10:1, 5\% triethylamine).

Yield: $65.1 \mathrm{mg}$ ( $0.39 \mathrm{mmol}, 78 \%)$; colorless oil, turns brown in air. IR (KBr): 3414, 2927, 2840, 1600, 1493, 1298, $804 \mathrm{~cm}^{-1}$.

${ }^{1} \mathrm{H}$ NMR $\left(300 \mathrm{MHz}, \mathrm{CDCl}_{3}, 20{ }^{\circ} \mathrm{C}\right): \delta=6.92-6.86(\mathrm{~m}, 2 \mathrm{H}, \mathrm{Ar}-\mathrm{H}), 6.41-$ $6.39(\mathrm{~m}, 1 \mathrm{H}, \mathrm{Ar}-\mathrm{H}), 3.85(\mathrm{~s}, 1 \mathrm{H}, \mathrm{N}-\mathrm{H}), 3.28\left(\mathrm{t}, J=5.5 \mathrm{~Hz}, 2 \mathrm{H}, \mathrm{CH}_{2}\right)$, $2.72\left(\mathrm{t}, J=6.4 \mathrm{~Hz}, 2 \mathrm{H}, \mathrm{CH}_{2}\right), 1.96-1.86\left(\mathrm{~m}, 2 \mathrm{H}, \mathrm{CH}_{2}\right)$.

${ }^{13} \mathrm{C}$ NMR $\left(75.5 \mathrm{MHz}, \mathrm{CDCl}_{3}, 20{ }^{\circ} \mathrm{C}\right): \delta=143.3,129.2,126.6,123.1$, 121.4, 115.3, 42.0, 27.0, 21.8 .

HRMS (ESI): $m / z[M+\mathrm{H}]^{+}$calcd for $\mathrm{C}_{9} \mathrm{H}_{11} \mathrm{ClN}$ : 168.05745; found: 168.05724 . 


\section{8-Chloro-1,2,3,4-tetrahydroquinoline (2q)}

The title compound was prepared according to procedure $C$ from $\mathbf{1 q}$ ( $81.5 \mathrm{mg}, 0.498 \mathrm{mmol}$ ) and then purified by column chromatography (silica gel, heptane/EtOAc 20:1, 2\% triethylamine).

Yield: $65.9 \mathrm{mg}$ (0.39 mmol, 79\%); colorless oil, turns brown in air. IR (KBr): 3423, 2929, 2839, 1601, 1498, 1298, 754, $720 \mathrm{~cm}^{-1}$.

${ }^{1} \mathrm{H}$ NMR $\left(300 \mathrm{MHz}, \mathrm{CDCl}_{3}, 20{ }^{\circ} \mathrm{C}\right): \delta=7.07(\mathrm{t}, J=7.9 \mathrm{~Hz}, 1 \mathrm{H}, \mathrm{Ar}-\mathrm{H})$, $6.86(\mathrm{~d}, J=7.4 \mathrm{~Hz}, 1 \mathrm{H}, \mathrm{Ar}-\mathrm{H}), 6.52(\mathrm{t}, J=7.7 \mathrm{~Hz}, 1 \mathrm{H}, \mathrm{Ar}-\mathrm{H}), 4.42(\mathrm{~s}, 1 \mathrm{H}$, $\mathrm{N}-\mathrm{H}), 3.44-3.35\left(\mathrm{~m}, 2 \mathrm{H}, \mathrm{CH}_{2}\right), 2.79\left(\mathrm{t}, J=6.4 \mathrm{~Hz}, 2 \mathrm{H}, \mathrm{CH}_{2}\right), 2.00-1.89$ (m, $2 \mathrm{H}, \mathrm{CH}_{2}$ ).

${ }^{13} \mathrm{C}$ NMR $\left(75.5 \mathrm{MHz}, \mathrm{CDCl}_{3}, 20{ }^{\circ} \mathrm{C}\right): \delta=140.8,127.8,126.9,122.7$, $118.2,116.4,41.9,27.3,21.8$.

HRMS (ESI): $m / z[\mathrm{M}+\mathrm{H}]^{+}$calcd for $\mathrm{C}_{9} \mathrm{H}_{11} \mathrm{ClN}$ : 168.05745; found: 168.05772 .

\section{6-Bromo-1,2,3,4-tetrahydroquinoline (2r)}

The title compound was synthesized according to procedure $C$ from 1r (103.5 $\mathrm{mg}, 0.50 \mathrm{mmol})$ and then purified by column chromatography (silica gel, heptane/EtOAc 10:1).

Yield: $60.7 \mathrm{mg}$ (0.29 mmol, 58\%); colorless oil, turns brown in air.

IR (KBr): 3415, 2926, 2839, 1597, 1491, 1296, $802 \mathrm{~cm}^{-1}$.

${ }^{1} \mathrm{H}$ NMR $\left(300 \mathrm{MHz}, \mathrm{CDCl}_{3}, 20{ }^{\circ} \mathrm{C}\right): \delta=7.08-6.99(\mathrm{~m}, 2 \mathrm{H}, \mathrm{Ar}-\mathrm{H}), 6.33(\mathrm{~d}$, $J=8.2 \mathrm{~Hz}, 1 \mathrm{H}, \mathrm{Ar}-\mathrm{H}), 3.85(\mathrm{~s}, 1 \mathrm{H}, \mathrm{N}-\mathrm{H}), 3.28\left(\mathrm{t}, J=5.5 \mathrm{~Hz}, 2 \mathrm{H}, \mathrm{CH}_{2}\right)$, $2.72\left(\mathrm{t}, J=6.4 \mathrm{~Hz}, 2 \mathrm{H}, \mathrm{CH}_{2}\right), 1.96-1.86\left(\mathrm{~m}, 2 \mathrm{H}, \mathrm{CH}_{2}\right)$.

${ }^{13} \mathrm{C}$ NMR $\left(75.5 \mathrm{MHz}, \mathrm{CDCl}_{3}, 20{ }^{\circ} \mathrm{C}\right): \delta=143.7,132.0,129.4,123.6$, 115.7, 108.0, 41.9, 26.9, 21.8 .

HRMS (ESI): $m / z[M+\mathrm{H}]^{+}$calcd for $\mathrm{C}_{9} \mathrm{H}_{11} \mathrm{BrN}$ : 212.00694; found: 212.00690

\section{2-Phenyl-1,2,3,4-tetrahydroquinoline (2t)}

The title compound was synthesized according to procedure B from $1 t(100.0 \mathrm{mg}, 0.49 \mathrm{mmol})$ and then purified by column chromatography (silica gel, heptane/EtOAc 100:1).

Yield: $72.7 \mathrm{mg}$ (0.35 mmol, 71\%); colorless oil, turns brown in air. IR (KBr): 3400, 3025, 2922, 2841, 1606, 1479, 1309, 743, $698 \mathrm{~cm}^{-1}$.

${ }^{1} \mathrm{H}$ NMR $\left(300 \mathrm{MHz}, \mathrm{CDCl}_{3}, 20{ }^{\circ} \mathrm{C}\right): \delta=7.45-7.27(\mathrm{~m}, 5 \mathrm{H}, \mathrm{Ar}-\mathrm{H}), 7.08-$ $6.98(\mathrm{~m}, 2 \mathrm{H}, \mathrm{Ar}-\mathrm{H}), 6.67(\mathrm{t}, J=7.4 \mathrm{~Hz}, 1 \mathrm{H}, \mathrm{Ar}-\mathrm{H}), 6.56(\mathrm{~d}, J=7.9 \mathrm{~Hz}, 1$ $\mathrm{H}, \mathrm{Ar}-\mathrm{H}), 4.46$ (dd, $J=9.2,3.3 \mathrm{~Hz}, 1 \mathrm{H}, \mathrm{CH}), 4.05(\mathrm{~s}, 1 \mathrm{H}, \mathrm{N}-\mathrm{H}), 3.02-$ $2.87\left(\mathrm{~m}, 1 \mathrm{H}, \mathrm{CH}_{2}\right), 2.82-2.69\left(\mathrm{~m}, 1 \mathrm{H}, \mathrm{CH}_{2}\right), 2.20-2.09\left(\mathrm{~m}, 2 \mathrm{H}, \mathrm{CH}_{2}\right)$.

${ }^{13} \mathrm{C}$ NMR $\left(75.5 \mathrm{MHz}, \mathrm{CDCl}_{3}, 20{ }^{\circ} \mathrm{C}\right): \delta=144.9,144.8,129.4,128.7$, 127.6, 127.0, 126.7, 121.0, 117.3, 114.1, 56.4, 31.1, 26.5 .

HRMS (ESI): $m / z[M+H]^{+}$calcd for $\mathrm{C}_{15} \mathrm{H}_{16} \mathrm{~N}$ : 210.12773; found: 210.12762 .

\section{6-(Naphthalen-1-yl)-1,2,3,4-tetrahydroquinoline ( $2 \mathrm{u})$}

The title compound was synthesized according to procedure B from $1 \mathbf{u}$ (113.1 mg, $0.44 \mathrm{mmol}$ ).

Yield: $113.5 \mathrm{mg}$ (0.44 mmol, 99\%); yellow oil, turns brown in air.

IR (KBr): 3405, 3042, 2925, 2838, 1732, 1611, 1503, 1352, 1301, 776 $\mathrm{cm}^{-1}$.

${ }^{1} \mathrm{H}$ NMR $\left(300 \mathrm{MHz}, \mathrm{CDCl}_{3}, 20{ }^{\circ} \mathrm{C}\right): \delta=8.09(\mathrm{~d}, J=8.2 \mathrm{~Hz}, 1 \mathrm{H}, \mathrm{Ar}-\mathrm{H})$, 7.92 (d, $J=7.8 \mathrm{~Hz}, 1 \mathrm{H}, \mathrm{Ar}-\mathrm{H}), 7.84(\mathrm{~d}, J=8.1 \mathrm{~Hz}, 1 \mathrm{H}, \mathrm{Ar}-\mathrm{H}), 7.57-7.41$ (m, $4 \mathrm{H}, \mathrm{Ar}-\mathrm{H}), 7.21-7.14(\mathrm{~m}, 2 \mathrm{H}, \mathrm{Ar}-\mathrm{H}), 6.69$ (d, J = 8.3 Hz, $1 \mathrm{H}, \mathrm{Ar}-\mathrm{H})$, $4.14(\mathrm{~s}, 1 \mathrm{H}, \mathrm{N}-\mathrm{H}), 4.11\left(\mathrm{t}, J=5.5 \mathrm{~Hz}, 2 \mathrm{H}, \mathrm{CH}_{2}\right), 2.88(\mathrm{t}, J=6.3 \mathrm{~Hz}, 2 \mathrm{H}$, $\mathrm{CH}_{2}$ ), 2.05 (quint, $J=6.0 \mathrm{~Hz}, 2 \mathrm{H}, \mathrm{CH}_{2}$ ).
${ }^{13} \mathrm{C}$ NMR $\left(75.5 \mathrm{MHz}, \mathrm{CDCl}_{3}, 20{ }^{\circ} \mathrm{C}\right): \delta=143.5,140.7,134.0,132.0$, $131.3,130.0,128.6,128.3,126.9,126.8,126.5,125.8,125.7,125.6$, $121.8,114.6,42.3,27.0,22.2$

HRMS (ESI): $m / z$ [M $+\mathrm{H}]^{+}$calcd for $\mathrm{C}_{19} \mathrm{H}_{18} \mathrm{~N}$ : 260.14338; found: 260.14355.

\section{3-(Isoquinolin-1-yl)-1,2,3,4-tetrahydroquinoline (2v)}

The title compound was synthesized according to procedure B from 1v (126.8 mg, $0.495 \mathrm{mmol}$ ).

Yield: $63.9 \mathrm{mg}$ (0.25 mmol, 50\%); white amorphous powder; mp 107$109^{\circ} \mathrm{C}$.

IR (KBr): 3394, 3010, 2922, 2818, 1579, 1494, 1310, 1250, 834, 753, $431 \mathrm{~cm}^{-1}$.

${ }^{1} \mathrm{H}$ NMR $\left(300 \mathrm{MHz}, \mathrm{CDCl}_{3}, 20{ }^{\circ} \mathrm{C}\right): \delta=8.53(\mathrm{~d}, J=5.7 \mathrm{~Hz}, 1 \mathrm{H}, \mathrm{Ar}-\mathrm{H})$, $8.28(\mathrm{~d}, J=8.4 \mathrm{~Hz}, 1 \mathrm{H}, \mathrm{Ar}-\mathrm{H}), 7.86(\mathrm{~d}, J=7.8 \mathrm{~Hz}, 1 \mathrm{H}, \mathrm{Ar}-\mathrm{H}), 7.73-7.66$ (m, $1 \mathrm{H}, \mathrm{Ar}-\mathrm{H}), 7.65-7.52(\mathrm{~m}, 2 \mathrm{H}, \mathrm{Ar}-\mathrm{H}), 7.12-7.00(\mathrm{~m}, 2 \mathrm{H}, \mathrm{Ar}-\mathrm{H})$, 6.74-6.60 (m, 2 H, Ar-H), 4.25-4.03 (m, 2 H, CH, N-H), $3.74(\mathrm{t}, J=10.9$ $\left.\mathrm{Hz}, 1 \mathrm{H}, \mathrm{CH}_{2}\right), 3.66-3.57\left(\mathrm{~m}, 1 \mathrm{H}, \mathrm{CH}_{2}\right), 3.52-3.37\left(\mathrm{~m}, 1 \mathrm{H}, \mathrm{CH}_{2}\right), 3.06$ (dq, $J=16.1,2.1 \mathrm{~Hz}, 1 \mathrm{H}, \mathrm{CH}_{2}$ ).

${ }^{13} \mathrm{C}$ NMR $\left(75.5 \mathrm{MHz}, \mathrm{CDCl}_{3}, 20{ }^{\circ} \mathrm{C}\right): \delta=162.3,144.3,142.2,136.4$, 129.9, 129.7, 127.7, 127.4, 127.1, 126.8, 124.6, 121.8, 119.6, 117.2, 114.3, 47.1, 36.0, 33.9.

HRMS (ESI): $m / z[M+H]^{+}$calcd for $\mathrm{C}_{18} \mathrm{H}_{17} \mathrm{~N}_{2}: 261.13862$; found: 261.13887.

\section{1-Methyl-1,2,3,4-tetrahydroquinoline (2w)}

The title compound was synthesized according to procedure $\mathrm{B}$ from $1 \mathbf{w}\left(134.2 \mathrm{mg}, 0.50 \mathrm{mmol}\right.$ ) in a mixture of $\mathrm{H}_{2} \mathrm{O} / \mathrm{MeOH}(1: 1)$; the product was obtained by subsequent extraction with heptane.

Yield: $16.5 \mathrm{mg}$ (0.112 mmol, 23\%); pale-yellow oil.

IR (KBr): 2926, 1601, 1498, 1320, 1207, $741 \mathrm{~cm}^{-1}$.

${ }^{1} \mathrm{H}$ NMR (300 MHz, $\left.\mathrm{CDCl}_{3}, 20{ }^{\circ} \mathrm{C}\right): \delta=7.12-7.04(\mathrm{~m}, 1 \mathrm{H}, \mathrm{Ar}-\mathrm{H}), 7.00-$ $6.93(\mathrm{~m}, 1 \mathrm{H}, \mathrm{Ar}-\mathrm{H}), 6.66-6.57(\mathrm{~m}, 2 \mathrm{H}, \mathrm{Ar}-\mathrm{H}), 3.23(\mathrm{t}, J=5.6 \mathrm{~Hz}, 2 \mathrm{H}$, $\left.\mathrm{CH}_{2}\right), 2.89\left(\mathrm{~s}, 3 \mathrm{H}, \mathrm{CH}_{3}\right), 2.78\left(\mathrm{t}, J=6.5 \mathrm{~Hz}, 2 \mathrm{H}, \mathrm{CH}_{2}\right), 2.04-1.93(\mathrm{~m}, 2 \mathrm{H}$, $\mathrm{CH}_{2}$ ).

${ }^{13} \mathrm{C}$ NMR $\left(75.5 \mathrm{MHz}, \mathrm{CDCl}_{3}, 20{ }^{\circ} \mathrm{C}\right): \delta=146.9,128.9,127.2,123.0$, 116.3, 111.1, 51.4, 39.3, 27.9, 22.6

HRMS (ESI): $m / z[\mathrm{M}+\mathrm{H}]^{+}$calcd for $\mathrm{C}_{10} \mathrm{H}_{14} \mathrm{~N}$ : 148.11208; found: 148.11203.

\section{Quinoline (1a)}

The title compound was synthesized according to procedure B from 1x (66.6 mg, $0.46 \mathrm{mmol})$.

Yield: $26.4 \mathrm{mg}$ (0.20 mmol, 45\%); yellow oil.

IR (KBr): 3396, 3057, 3037, 1500, 1314, 1118, 802, $784 \mathrm{~cm}^{-1}$.

${ }^{1} \mathrm{H}$ NMR $\left(300 \mathrm{MHz}, \mathrm{CDCl}_{3}, 20{ }^{\circ} \mathrm{C}\right): \delta=8.91(\mathrm{dd}, J=4.2,1.4 \mathrm{~Hz}, 1 \mathrm{H}, \mathrm{Ar}-$ $\mathrm{H}), 8.17-8.07$ ( $\mathrm{m}, 2 \mathrm{H}, \mathrm{Ar}-\mathrm{H}$ ), 7.80 (dd, $J=8.1,1.2 \mathrm{~Hz}, 1 \mathrm{H}, \mathrm{Ar}-\mathrm{H}), 7.74-$ 7.67 ( $\mathrm{m}, 1 \mathrm{H}, \mathrm{Ar}-\mathrm{H}), 7.57-7.49$ (m, $1 \mathrm{H}, \mathrm{Ar}-\mathrm{H}), 7.38$ (dd, $J=4.2,4.2 \mathrm{~Hz}$, $1 \mathrm{H}, \mathrm{Ar}-\mathrm{H})$.

${ }^{13} \mathrm{C}$ NMR $\left(75.5 \mathrm{MHz}, \mathrm{CDCl}_{3}, 20{ }^{\circ} \mathrm{C}\right): \delta=150.5,148.4,136.2,129.6$, 129.5, 128.4, 127.9, 126.6, 121.2

HRMS (ESI): $m / z\left[M+\mathrm{H}^{+}\right.$calcd for $\mathrm{C}_{9} \mathrm{H}_{8} \mathrm{~N}$ : 130.06513; found: 130.06520 . 


\section{Indoline (2y)}

The title compound was prepared according to procedure B from $\mathbf{1 y}$ ( $57.3 \mathrm{mg}, 0.49 \mathrm{mmol}$ ) and then purified by column chromatography (silica gel, heptane/EtOAc 5:1).

Yield: $28.9 \mathrm{mg}$ ( $0.24 \mathrm{mmol}, 50 \%)$; yellow oil, turns brown in air.

IR (KBr): 3408, 3052, 2925, 2851, 1606, 1485, 1455, $740 \mathrm{~cm}^{-1}$.

${ }^{1} \mathrm{H}$ NMR $\left(300 \mathrm{MHz}, \mathrm{CDCl}_{3}, 20{ }^{\circ} \mathrm{C}\right): \delta=7.13(\mathrm{~d}, J=7.3 \mathrm{~Hz}, 1 \mathrm{H}, \mathrm{Ar}-\mathrm{H})$, 7.07-6.98 (m, $1 \mathrm{H}, \mathrm{Ar}-\mathrm{H}), 6.75-6.63(\mathrm{~m}, 2 \mathrm{H}, \mathrm{Ar}-\mathrm{H}), 3.56(\mathrm{t}, J=8.4 \mathrm{~Hz}, 2$ $\left.\mathrm{H}, \mathrm{CH}_{2}\right), 3.04\left(\mathrm{t}, J=8.4 \mathrm{~Hz}, 2 \mathrm{H}, \mathrm{CH}_{2}\right)$.

${ }^{13} \mathrm{C}$ NMR $\left(75.5 \mathrm{MHz}, \mathrm{CDCl}_{3}, 20{ }^{\circ} \mathrm{C}\right): \delta=151.7,129.4,127.3,124.7$, 118.8, 109.6, 47.4, 30.0.

HRMS (ESI): $m / z[M+H]^{+}$calcd for $\mathrm{C}_{8} \mathrm{H}_{10} \mathrm{~N}$ : 120.08078; found: 120.08121

\section{1,2,3,4-Tetrahydro-1,5-naphthyridine (2z)}

The title compound was prepared according to procedure $\mathrm{A}$ from $\mathbf{1 z}$ (65.9 mg, $0.51 \mathrm{mmol}$ ).

Yield: $66.2 \mathrm{mg}$ (0.49 mmol, 97\%); white-yellow powder; mp 112-114 ${ }^{\circ} \mathrm{C}$.

IR (KBr): 3225, 2949, 2931, 2833, 1579, 1454, 1297, 1268, 791, 731 $\mathrm{cm}^{-1}$.

${ }^{1} \mathrm{H}$ NMR $\left(300 \mathrm{MHz}, \mathrm{CDCl}_{3}, 20{ }^{\circ} \mathrm{C}\right): \delta=7.77(\mathrm{dd}, J=4.7,1.2 \mathrm{~Hz}, 1 \mathrm{H}, \mathrm{Ar}-$ H), $6.80(\mathrm{dd}, J=8.1,4.7 \mathrm{~Hz}, 1 \mathrm{H}, \mathrm{Ar}-\mathrm{H}), 6.64(\mathrm{dd}, J=8.1,1.3 \mathrm{~Hz}, 1 \mathrm{H}, \mathrm{Ar}-$ $\mathrm{H}), 4.36(\mathrm{~s}, 1 \mathrm{H}, \mathrm{N}-\mathrm{H}), 3.21\left(\mathrm{t}, J=5.5 \mathrm{~Hz}, 2 \mathrm{H}, \mathrm{CH}_{2}\right), 2.85(\mathrm{t}, J=6.5 \mathrm{~Hz}, 2$ $\left.\mathrm{H}, \mathrm{CH}_{2}\right), 1.99-1.88\left(\mathrm{~m}, 2 \mathrm{H}, \mathrm{CH}_{2}\right)$.

${ }^{13} \mathrm{C}$ NMR $\left(75.5 \mathrm{MHz}, \mathrm{CDCl}_{3}, 20{ }^{\circ} \mathrm{C}\right): \delta=142.5,141.0,137.5,121.9$, 120.2, 41.4, 30.2, 21.6.

HRMS (ESI): $m / z$ [M $+\mathrm{H}]^{+}$calcd for $\mathrm{C}_{8} \mathrm{H}_{11} \mathrm{~N}_{2}$ : 135.09167; found: 135.09183

\section{2,3-Dihydrobenzofuran (2aa)}

The title compound was synthesized according to procedure B from 1aa ( $58.9 \mathrm{mg}, 0.50 \mathrm{mmol}$ ) and then purified by column chromatography (silica gel, pentane/DCM 1:1).

Yield: $12.2 \mathrm{mg}$ ( $0.10 \mathrm{mmol}, 20 \%)$; colorless oil.

IR (KBr): 2923, 2853, 1597, 1483, 1461, 1227, 983, $746 \mathrm{~cm}^{-1}$.

${ }^{1} \mathrm{H}$ NMR $\left(300 \mathrm{MHz}, \mathrm{CDCl}_{3}, 20{ }^{\circ} \mathrm{C}\right): \delta=7.23-7.17(\mathrm{~m}, 1 \mathrm{H}, \mathrm{Ar}-\mathrm{H}), 7.15-$ $7.07(\mathrm{~m}, 1 \mathrm{H}, \mathrm{Ar}-\mathrm{H}), 6.88-6.75(\mathrm{~m}, 2 \mathrm{H}, \mathrm{Ar}-\mathrm{H}), 4.56(\mathrm{t}, J=8.6 \mathrm{~Hz}, 2 \mathrm{H}$, $\left.\mathrm{CH}_{2}\right), 3.21\left(\mathrm{t}, \mathrm{J}=8.7 \mathrm{~Hz}, 2 \mathrm{H}, \mathrm{CH}_{2}\right)$.

${ }^{13} \mathrm{C}$ NMR $\left(75.5 \mathrm{MHz}, \mathrm{CDCl}_{3}, 20{ }^{\circ} \mathrm{C}\right): \delta=160.1,128.1,127.0,125.0$, $120.5,109.5,71.1,29.9$.

HRMS (ESI): product not detected; MS (EI): $m / z=120,91,65,63,51$, 39.

\section{Furan-2-ylmethanol (2ab)}

The title compound was prepared from 1ab $(47.8 \mathrm{mg}, 0.50 \mathrm{mmol})$ and $\mathrm{Co}(\mathrm{OAc})_{2} \cdot 4 \mathrm{H}_{2} \mathrm{O}(3 \mathrm{~mol} \%)$ and $\mathrm{Zn}(30 \mathrm{~mol} \%)$.

Yield: $47.5 \mathrm{mg}$ (0.48 mmol, 97\%); pale-yellow liquid.

IR (KBr): 3327, 2929, 2873, 1504, 1147, 1008, 913, $791 \mathrm{~cm}^{-1}$.

${ }^{1} \mathrm{H}$ NMR $\left(300 \mathrm{MHz}, \mathrm{CDCl}_{3}, 20{ }^{\circ} \mathrm{C}\right): \delta=7.37(\mathrm{dd}, J=1.8,0.7 \mathrm{~Hz}, 1 \mathrm{H}, \mathrm{Ar}-$ $\mathrm{H}), 6.34-6.28(\mathrm{~m}, 1 \mathrm{H}, \mathrm{Ar}-\mathrm{H}), 6.28-6.22(\mathrm{~m}, 1 \mathrm{H}, \mathrm{Ar}-\mathrm{H}), 4.54(\mathrm{~s}, 2 \mathrm{H}$, $\left.\mathrm{CH}_{2}\right), 2.78(\mathrm{~s}, 1 \mathrm{H}, \mathrm{O}-\mathrm{H})$.

${ }^{13} \mathrm{C}$ NMR $\left(75.5 \mathrm{MHz}, \mathrm{CDCl}_{3}, 20{ }^{\circ} \mathrm{C}\right): \delta=154.2,142.6,110.4,107.8,57.3$. HRMS (ESI): product not detected; MS (EI): $m / z=98,81,69,53,41$, 39, 29.

\section{(Tetrahydrofuran-2-yl)methanol (2ab')}

The title compound was synthesized according to procedure B from 1ab ( $48.3 \mathrm{mg}, 0.503 \mathrm{mmol}$ ) and then purified by column chromatography (silica gel, DCM/MeOH 50:1).

Yield: $26.6 \mathrm{mg}$ ( $0.26 \mathrm{mmol}, 52 \%)$; colorless oil.

IR (KBr): 3390, 2927, 2872, 1710, 1460, 1056, $773 \mathrm{~cm}^{-1}$.

${ }^{1} \mathrm{H}$ NMR $\left(300 \mathrm{MHz}, \mathrm{CDCl}_{3}, 20{ }^{\circ} \mathrm{C}\right): \delta=4.05-3.95\left(\mathrm{~m}, 1 \mathrm{H}, \mathrm{CH}_{2}\right), 3.90-$ $3.72(\mathrm{~m}, 2 \mathrm{H}, \mathrm{CH}), 3.65$ (dd, $\left.J=11.6,3.2 \mathrm{~Hz}, 1 \mathrm{H}, \mathrm{CH}_{2}\right), 3.48$ (dd, $J=11.6$, $\left.6.2 \mathrm{~Hz}, 1 \mathrm{H}, \mathrm{CH}_{2}\right), 2.31(\mathrm{~s}, 1 \mathrm{H}, \mathrm{O}-\mathrm{H}), 1.97-1.83\left(\mathrm{~m}, 3 \mathrm{H}, \mathrm{CH}_{2}\right), 1.69-1.56$ ( $\mathrm{m}, 1 \mathrm{H}, \mathrm{CH}_{2}$ ).

${ }^{13} \mathrm{C}$ NMR $\left(75.5 \mathrm{MHz}, \mathrm{CDCl}_{3}, 20{ }^{\circ} \mathrm{C}\right): \delta=79.6,68.4,65.0,27.2,26.1$.

HRMS (ESI): product not detected; MS (EI): $m / z=71,43,41,31,29,27$.

\section{Conflict of Interest}

The authors declare no conflict of interest.

\section{Funding Information}

Financial support was provided by the Austrian Science Fund (FWF), Standalone Project P 32045 'Metallocorrole-Based Catalysts for Biomass Valorization'. For the purpose of open access, the author has applied a CC BY 4.0 public copyright license to any Author Accepted Manuscript version arising from this submission.

\section{Acknowledgments}

We gratefully thank Prof. Dr. Marko Hapke from the INCA and Prof. Dr. Wolfgang Schöfberger from the Institute of Organic Chemistry (both $\mathrm{JKU}$ ) for fruitful discussions and generous support. Moreover, we are much obliged to DI Thomas Bögl from the Department of Analytical Chemistry at JKU for performing the HRMS measurements of the various hydrogenation products.

\section{Supporting Information}

Supporting information for this article is available online at https://doi.org/10.1055/a-1654-3302.

\section{References}

(1) Scott, J.; Williams, R. Chem. Rev. 2002, 102, 1669.

(2) (a) Katritzky, A.; Rachwal, S.; Rachwal, B. Tetrahedron 1996, 52, 15031. (b) Sridharan, V.; Suryavanshi, P.; Menéndez, J. Chem. Rev. 2011, 111, 7157. (c) Muthukrishnan, I.; Sridharan, V.; Menéndez, J. Chem. Rev. 2019, 119, 5057.

(3) (a) Jardine, I.; McQuillin, F. J. Chem. Soc. D 1970, 626a. (b) Wen, J.; Tan, R.; Liu, S.; Zhao, Q.; Zhang, X. Chem. Sci. 2016, 7, 3047. (c) Kim, S.; Loose, F.; Bezdek, M.; Wang, X.; Chirik, P. J. Am. Chem. Soc. 2019, 141, 17900.

(4) (a) Wang, W.; Lu, S.; Yang, P.; Han, X.; Zhou, Y. J. Am. Chem. Soc. 2003, 125, 10536. (b) Li, H.; Jiang, J.; Lu, G.; Huang, F.; Wang, Z.X. Organometallics 2011, 30, 3131. (c) Dobereiner, G.; Nova, A.; Schley, N.; Hazari, N.; Miller, S.; Eisenstein, O.; Crabtree, R.J. Am. Chem. Soc. 2011, 133, 7547. (d) Wu, J.; Barnard, J.; Zhang, Y.; Talwar, D.; Robertson, C.; Xiao, J. Chem. Commun. 2013, 49, 7052. (e) Vivancos, Á.; Beller, M.; Albrecht, M. ACS Catal. 2017, $8,17$. 
(5) (a) Rosales, M.; Navarro, J.; Sánchez, L.; González, A.; Alvarado, Y.; Rubio, R.; De La Cruz, C.; Rajmankina, T. Transition Met. Chem. 1996, 21, 11. (b) Zhou, H.; Li, Z.; Wang, Z.; Wang, T.; Xu, L.; He, Y.; Fan, Q.; Pan, J.; Gu, L.; Chan, A. Angew. Chem. Int. Ed. 2008, 47, 8464. (c) Chatterjee, B.; Kalsi, D.; Kaithal, A.; Bordet, A.; Leitner, W.; Gunanathan, C. Catal. Sci. Technol. 2020, 10, 5163. (d) Li, C.; Pan, Y.; Feng, Y.; He, Y.; Liu, Y.; Fan, Q. Org. Lett. 2020, 22, 6452. (e) Rosales, M.; Molina, K.; Arrieta, F.; Fernández, D.; Baricelli, P. Mol. Catal. 2020, 490, 110970.

(6) Cai, X.; Huang, W.; Chen, Z.; Zhou, Y. Chem. Commun. 2014, 50, 9588.

(7) Chelucci, G.; Baldino, S.; Baratta, W. Acc. Chem. Res. 2015, 48, 363.

(8) Fish, R.; Thormodsen, A.; Cremer, G. J. Am. Chem. Soc. 1982, 104, 5234.

(9) (a) Wang, Y.; Zhu, L.; Shao, Z.; Li, G.; Lan, Y.; Liu, Q. J. Am. Chem. Soc. 2019, 141, 17337. (b) Papa, V.; Cao, Y.; Spannenberg, A.; Junge, K.; Beller, M. Nat. Catal. 2020, 3, 135. (c) Tan, Z.; Xiong, B.; Yang, J.; Ci, C.; Jiang, H.; Zhang, M. J. Catal. 2020, 392, 135. (d) Liu, C.; Wang, M.; Liu, S.; Wang, Y.; Peng, Y.; Lan, Y.; Liu, Q. Angew. Chem. Int. Ed. 2021, 60, 5108.

(10) Chakraborty, S.; Brennessel, W.; Jones, W. J. Am. Chem. Soc. 2014, 136, 8564.

(11) Zhu, G.; Pang, K.; Parkin, G. J. Am. Chem. Soc. 2008, 130, 1564.

(12) (a) Alvanipour, A.; Kispert, L. J. Mol. Catal. 1988, 48, 277. (b) Xu, R.; Chakraborty, S.; Yuan, H.; Jones, W. ACS Catal. 2015, 5, 6350. (c) Adam, R.; Cabrero-Antonino, J.; Spannenberg, A.; Junge, K.; Jackstell, R.; Beller, M. Angew. Chem. Int. Ed. 2017, 56, 3216. (d) Duan, Y.; Du, X.; Cui, Z.; Zeng, Y.; Liu, Y.; Yang, T.; Wen, J.; Zhang, X. J. Am. Chem. Soc. 2019, 141, 20424. (e) Sandl, S.; Maier, T.; van Leest, N.; Kröncke, S.; Chakraborty, U.; Demeshko, S.; Koszinowski, K.; de Bruin, B.; Meyer, F.; Bodensteiner, M.; Herrmann, C.; Wolf, R.; Jacobi von Wangelin, A. ACS Catal. 2019, 9, 7596.

(13) Cabrero-Antonino, J.; Adam, R.; Junge, K.; Jackstell, R.; Beller, M. Catal. Sci. Technol. 2017, 7, 1981.

(14) (a) Pang, M.; Chen, J.; Zhang, S.; Liao, R.; Tung, C.; Wang, W. Nat. Commun. 2020, 11, 1249. (b) Maier, T. M.; Sandl, S.; Shenderovich, I. G.; Jacobi von Wangelin, A.; Weigand, J. J.; Wolf, R. Chem. Eur. J. 2019, 25, 238.

(15) Zhong, Y.; Zhou, T.; Zhang, Z.; Chang, R. ACS Omega 2019, 4, 8487.

(16) Alshakova, I.; Gabidullin, B.; Nikonov, G. ChemCatChem 2018 , $10,4860$.

(17) Zhang, L.; Qiu, R.; Xue, X.; Pan, Y.; Xu, C.; Li, H.; Xu, L. Adv. Synth. Catal. 2015, 357, 3759.

(18) (a) Wang, C.; Li, C.; Wu, X.; Pettman, A.; Xiao, J. Angew. Chem. Int. Ed. 2009, 48, 6524. (b) Wang, Y.; Huang, Z.; Leng, X.; Zhu, H.; Liu, G.; Huang, Z. J. Am. Chem. Soc. 2018, 140, 4417.

(19) (a) Handbook of Heterogeneous Catalytic Hydrogenation for Organic Synthesis; Nishimura, S., Ed.; Wiley: New York, 2001. (b) Wei, Z.; Shao, F.; Wang, J. Chin. J. Catal. 2019, 40, 980.

(20) (a) Hashimoto, N.; Takahashi, Y.; Hara, T.; Shimazu, S.; Mitsudome, T.; Mizugaki, T.; Jitsukawa, K.; Kaneda, K. Chem. Lett. 2010, 39, 832. (b) Rahi, R.; Fang, M.; Ahmed, A.; SánchezDelgado, R. Dalton Trans. 2012, 41, 14490. (c) Mao, H.; Ma, J.; Liao, Y.; Zhao, S.; Liao, X. Catal. Sci. Technol. 2013, 3, 1612. (d) Xia, Y.; Ma, J.; Wang, X.; Yang, L.; Wu, L. Catal. Sci. Technol. 2017, 7, 5515. (e) Wang, L.; Chen, M.-X.; Yan, Q.-Q.; Xu, S.-L.; Chu, S.-Q.; Chen, P.; Lin, Y.; Liang, H.-W. Sci. Adv. 2019, 5, eaax6322.
(21) (a) Campanati, M.; Casagrande, M.; Fagiolino, I.; Lenarda, M.; Storaro, L.; Battagliarin, M.; Vaccari, A. J. Mol. Catal. A: Chem. 2002, 184, 267. (b) Mévellec, V.; Roucoux, A. Inorg. Chim. Acta 2004, 357, 3099. (c) Fan, G.; Wu, J. Catal. Commun. 2013, 31, 81. (d) Niu, M.; Wang, Y.; Chen, P.; Du, D.; Jiang, J.; Jin, Z. Catal. Sci. Technol. 2015, 5, 4746. (e) Karakulina, A.; Gopakumar, A.; Akçok, İ.; Roulier, B.; LaGrange, T.; Katsyuba, S.; Das, S.; Dyson, P. Angew. Chem. Int. Ed. 2015, 55, 292. (f) Karakulina, A.; Gopakumar, A.; Fei, Z.; Dyson, P. Catal. Sci. Technol. 2018, 8, 5091.

(22) (a) Bianchini, C.; Dal Santo, V.; Meli, A.; Moneti, S.; Moreno, M.; Oberhauser, W.; Psaro, R.; Sordelli, L.; Vizza, F. J. Catal. 2003, 213, 47. (b) Sun, Y.; Fu, H.; Zhang, D.; Li, R.; Chen, H.; Li, X. Catal. Commun. 2010, 12, 188. (c) Fang, M.; Machalaba, N.; SánchezDelgado, R. Dalton Trans. 2011, 40, 10621. (d) Zhang, L.; Wang, X.; Xue, Y.; Zeng, X.; Chen, H.; Li, R.; Wang, S. Catal. Sci. Technol. 2014, 4, 1939. (e) Jiang, H.; Zheng, X. Catal. Sci. Technol. 2015, 5 , 3728. (f) Tang, M.; Deng, J.; Li, M.; Li, X.; Li, H.; Chen, Z.; Wang, Y. Green Chem. 2016, 18, 6082. (g) Sun, B.; Carnevale, D.; Süss-Fink, G. J. Organomet. Chem. 2016, 821, 197. (h) Ye, T.; Li, J.; Kitano, M.; Hosono, H. Green Chem. 2017, 19, 749. (i) Konnerth, H.; Prechtl, M. Green Chem. 2017, 19, 2762. (j) Cao, Y.; Zhang, H.; Liu, K.; Chen, K.-J. Chem. Commun. 2020, 56, 11311. (k) Cao, Y.; Ding, L.; Qiu, Z.; Zhang, H. Catal. Commun. 2020, 143, 106048.

(23) (a) Barbaro, P.; Gonsalvi, L.; Guerriero, A.; Liguori, F. Green Chem. 2012, 14, 3211. (b) Ji, Y.; Wei, K.; Liu, T.; Wu, L.; Zhang, W. Adv. Synth. Catal. 2017, 359, 933.

(24) Shaikh, M. N.; Kalanthoden, A. N.; Ali, M.; Haque, M. A.; Aziz, M. A.; Abdelnaby, M. M.; Rani, S. K.; Bakare, A. I. ChemistrySelect 2020, 5, 14827.

(25) (a) Ren, D.; He, L.; Yu, L.; Ding, R.-S.; Liu, Y.-M.; Cao, Y.; He, H.-Y.; Fan, K.-N. J. Am. Chem. Soc. 2012, 134, 17592. (b) Zhao, J.; Yuan, H.; Qin, X.; Tian, K.; Liu, Y.; Wei, C.; Zhang, Z.; Zhou, L.; Fang, S. Catal. Lett. 2020, 150, 2841.

(26) (a) Kaneda, K.; Mikami, Y.; Mitsudome, T.; Mizugaki, T.; Jitsukawa, K. Heterocycles 2010, 82, 1371. (b) Bathla, A.; Pal, B. J. Ind. Eng. Chem. 2019, 79, 314.

(27) Sahoo, B.; Kreyenschulte, C.; Agostini, G.; Lund, H.; Bachmann, S.; Scalone, M.; Junge, K.; Beller, M. Chem. Sci. 2018, 9, 8134.

(28) (a) Tsushima, S.; Sudzuki, S. J. Chem. Soc. Jpn. 1943, 64, 1925. (b) Ryabchuk, P.; Agostini, G.; Pohl, M.; Lund, H.; Agapova, A.; Junge, H.; Junge, K.; Beller, M. Sci. Adv. 2018, 4, eaat0761. (c) Ryabchuk, P.; Agapova, A.; Kreyenschulte, C.; Lund, H.; Junge, H.; Junge, K.; Beller, M. Chem. Commun. 2019, 55, 4969. (d) Yun, R.; Ma, W.; Hong, L.; Hu, Y.; Zhan, F.; Liu, S.; Zheng, B. Catal. Sci. Technol. 2019, 9, 6669. (e) Yang, X.; Niu, L.; Xia, Z.; Yan, X.; Bai, G. Mol. Catal. 2020, 493, 111094. (f) Yun, R.; Ma, Z.; Hu, Y.; Zhan, F.; Qiu, C.; Zheng, B.; Sheng, T. Catal. Lett. 2021.

(29) (a) Chen, F.; Surkus, A.; He, L.; Pohl, M.; Radnik, J.; Topf, C.; Junge, K.; Beller, M. J. Am. Chem. Soc. 2015, 137, 11718. (b) Wei, Z.; Chen, Y.; Wang, J.; Su, D.; Tang, M.; Mao, S.; Wang, Y. ACS Catal. 2016, 6, 5816. (c) Ji, P.; Manna, K.; Lin, Z.; Urban, A.; Greene, F.; Lan, G.; Lin, W. J. Am. Chem. Soc. 2016, 138, 12234. (d) Ji, P.; Song, Y.; Drake, T.; Veroneau, S.; Lin, Z.; Pan, X.; Lin, W. J. Am. Chem. Soc. 2017, 140, 433. (e) Sorribes, I.; Liu, L.; Doménech-Carbó, A.; Corma, A. ACS Catal. 2018, 8, 4545. (f) Jaiswal, G.; Subaramanian, M.; Sahoo, M.; Balaraman, E. ChemCatChem 2019, 11, 2449. (g) Yun, R.; Hong, L.; Ma, W.; Wang, S.; Zheng, B. ACS Appl. Nano Mater. 2019, 2, 6763. (h) Yun, R.; Hong, L.; Ma, W.; Zhang, R.; Zhan, F.; Duan, J.; Zheng, B.; Wang, S. ChemCatChem 2019, 12, 129. (i) Gong, W.; Yuan, Q.; Chen, C.; Lv, Y.; Lin, Y.; Liang, C.; Wang, G.; Zhang, H.; Zhao, H. Adv. Mater. 2019, 31, 1906051. (j) Rengshausen, S.; Van Stappen, 
C.; Levin, N.; Tricard, S.; Luska, K.; DeBeer, S.; Chaudret, B.; Bordet, A.; Leitner, W. Small 2020, 17, 2006683. (k) Murugesan, K.; Chandrashekhar, V.; Kreyenschulte, C.; Beller, M.; Jagadeesh, R. Angew. Chem. Int. Ed. 2020, 59, 17408. (1) Zhang, S.; Gan, J.; Xia, Z.; Chen, X.; Zou, Y.; Duan, X.; Qu, Y. Chem 2020, 6, 2994. (m) He, Z.; Sun, Y.; Wang, K.; Wang, Z.; Guo, P.; Jiang, C.; Yao, M.; Li, Z.; Liu, Z. Mol. Catal. 2020, 496, 111192. (n) Xu, D.; Zhao, H.; Dong, Z.; Ma, J. ChemCatChem 2020, 12, 4406.

(30) For a selection of seminal papers that exemplify this methodology, see: (a) Westerhaus, F.; Jagadeesh, R.; Wienhöfer, G.; Pohl, M.; Radnik, J.; Surkus, A.; Rabeah, J.; Junge, K.; Junge, H.; Nielsen, M.; Brückner, A.; Beller, M. Nat. Chem. 2013, 5, 537. (b) Jagadeesh, R.; Surkus, A.; Junge, H.; Pohl, M.; Radnik, J.; Rabeah, J.; Huan, H.; Schunemann, V.; Bruckner, A.; Beller, M. Science 2013, 342, 1073. (c) Cui, X.; Li, Y.; Bachmann, S.; Scalone, M.; Surkus, A.; Junge, K.; Topf, C.; Beller, M. J. Am. Chem. Soc. 2015, 137, 10652.

(31) Cobalt Catalysis in Organic Synthesis: Methods and Reactions; Hapke, M.; Hilt, G., Ed.; Wiley-VCH: Weinheim, 2020.

(32) (a) Chen, F.; Sahoo, B.; Kreyenschulte, C.; Lund, H.; Zeng, M.; He, L.; Junge, K.; Beller, M. Chem. Sci. 2017, 8, 6239. (b) Li, G.; Yang, H.; Zhang, H.; Qi, Z.; Chen, M.; Hu, W.; Tian, L.; Nie, R.; Huang, W. ACS Catal. 2018, 8, 8396. (c) Han, Y.; Wang, Z.; Xu, R.; Zhang, W.; Chen, W.; Zheng, L.; Zhang, J.; Luo, J.; Wu, K.; Zhu, Y.; Chen, C.; Peng, Q.; Liu, Q.; Hu, P.; Wang, D.; Li, Y. Angew. Chem. Int. Ed. 2018, 57, 11262. (d) Xu, D.; Zhao, H.; Dong, Z.; Ma, J. ChemCatChem 2019, 11, 5475. (e) Leng, Y.; Du, S.; Feng, G.; Sang, X.; Jiang, P.; Li, H.; Wang, D. ACS Appl. Mater. Interfaces 2019, 12, 474.

(33) For selected reviews on catalytically active nanoscale metal particles, see: (a) Bönnemann, H.; Richards, R. Eur. J. Inorg. Chem. 2001, 2455. (b) An, K.; Somorjai, G. Catal. Lett. 2014, 145, 233. (c) Liu, L.; Corma, A. Chem. Rev. 2018, 118, 4981.

(34) Sandl, S.; Schwarzhuber, F.; Pöllath, S.; Zweck, J.; Jacobi von Wangelin, A. Chem. Eur. J. 2018, 24, 3403.
(35) Hervochon, J.; Dorcet, V.; Junge, K.; Beller, M.; Fischmeister, C. Catal. Sci. Technol. 2020, 10, 4820.

(36) Büschelberger, P.; Reyes-Rodriguez, E.; Schöttle, C.; Treptow, J.; Feldmann, C.; Jacobi von Wangelin, A.; Wolf, R. Catal. Sci. Technol. 2018, 8, 2648.

(37) Banwell, M.; Jones, M.; Reekie, T.; Schwartz, B.; Tan, S.; White, L. Org. Biomol. Chem. 2014, 12, 7433.

(38) (a) Adkins, H.; Billica, H. J. Am. Chem. Soc. 1948, 70, 695. (b) Okazaki, H.; Onishi, K.; Soeda, M.; Ikefuji, Y.; Tamura, R.; Mochida, I. Bull. Chem. Soc. Jpn. 1990, 63, 3167. (c) A quenched skeletal $\mathrm{Ni}$ catalyst for the effective partial hydrogenation of various heterocycles is described in: Liu, C.; Rong, Z.; Sun, Z.; Wang, Y.; Du, W.; Wang, Y.; Lu, L. RSC Adv. 2013, 3, 23984.

(39) Cho, H.; Török, F.; Török, B. Org. Biomol. Chem. 2013, 11, 1209.

(40) Hayashi, E.; Yamanaka, H.; Iijima, C. Yakugaku Zasshi 1960, 80, 839.

(41) Stegner, P.; Färber, C.; Zenneck, U.; Knüpfer, C.; Eyselein, J.; Wiesinger, M.; Harder, S. Angew. Chem. Int. Ed. 2020, 60, 4252.

(42) Dai, H.; Guan, H. ACS Catal. 2018, 8, 9125.

(43) Timelthaler, D.; Topf, C. J. Org. Chem. 2019, 84, 11604.

(44) Hamlin, J. E.; Hirai, K.; Millan, A.; Maitlis, P. M. J. Mol. Catal. 1980, 7, 543.

(45) Balzani, V.; Credi, A.; Venturi, M. Molecular Devices and Machines: Concepts and Perspective for the Nanoworld, 2nd ed; Wiley-VCH: Weinheim, 2008.

(46) Water and quinolines are not indefinitely miscible.

(47) Titova, Y.; Schmidt, F. New J. Chem. 2021, 45, 4525.

(48) Pagliero, R. J.; Lusvarghi, S.; Pierini, A. B.; Brun, R.; Mazzieri, M. R. Bioorg. Med. Chem. 2010, 18, 142.

(49) Hardtmann, G. E. US Patent 4015005, 1977.

(50) Liou, J. P.; Wu, Z. Y.; Kuo, C. C.; Chang, C. Y.; Lu, P. Y.; Chen, C. M.; Hsieh, H. P.; Chang, J. Y. J. Med. Chem. 2008, 51, 4351.

(51) Balint, J.; Egri, G.; Fogassy, E.; Böcskei, Z.; Simon, K.; Gajaryband, A.; Friesz, A. Tetrahedron: Asymmetry 1999, 10, 1079.

(52) Ros, A.; Estepa, B.; López-Rodríguez, R.; Álvarez, E.; Fernández, R.; Lassaletta, J. Angew. Chem. Int. Ed. 2011, 50, 11724. 